\title{
TREATMENT AND RECYCLING ENGINEERING OF CHICKEN LITTER VIA THERMAL GASIFICATION PROCESS FOR WARMING POULTRY HOUSES
}

\author{
Said Elshahat Abdallah ${ }^{1}$ and Wael Mohamed Elmessery ${ }^{2}$
}

\begin{abstract}
Poultry industry, in Egypt, encounters a lot of problems and diseases especially at winter season. A lot of chicks are dying due to low temperatures at night. Poultry house warming requires a lot of energy using petroleum delivers such as liquefied petroleum gas (LPG). In this period of each year, the higher demand on LPG cylinders raises the crisis of energy shortage in Egypt. Add-value principle was considered for solving the problem. Chicken litter as a by-product of poultry production process can be recycled and reused as an alternative source of energy where there is no transportation is required especially at remote areas. Poultry house, under investigation, is located at 12 Elezbah Elbaidah village, Elhamoul district, Kafr Elsheikh governorate. According to data collected about weather conditions, the environment is almost at steady state conditions in the two months of January and February of 2016 during the period from 12:00AM to 7:00AM at $12^{\circ} \mathrm{C}$ and relative humidity of $70 \%$ to be suitable for experimentation. Poultry house was divided into two longitudinal sections called raceways. Thermal gasification technique is selected for biomass (chicken litter) energy conversion. Based on energy needs for warming process, the operation parameters and investigation variables of thermal gasification process were chosen. A continuous feeding fluidized bed reactor type with a catalyst sand bed was used. The system consists of gasifier reactor, chicken litter feeding section, cleaning section of two cyclones and gasifying agent supplying section.
\end{abstract}

Keywords: Chicken litter gasification, thermal energy magnification, heat balance

1. Associate Professor, Agricultural Engineering Department, Faculty of Agriculture, Kafrelsheikh University, Kafr Elsheikh 33516, Egypt

2. Lecturer, Agricultural Engineering Department, Faculty of Agriculture, Kafrelsheikh University, Kafr Elsheikh 33516, Egypt 
The effect of catalyst presence percent (Dolomite) of 20, 30 and 50\% in the sand bed, four levels of equivalence ratio of 0.326, 0.289, 0.227 and 0.202 , three different temperature profiles of 430,560 and $670^{\circ} \mathrm{C}$ and two types of gasifying agent of natural air and mixture of air with steam are investigated. Two pathways of energy outputs; energy released to surround environment around the gasifier reactor and by the product gas. Each energy pathway was directed to a specific raceway. An air temperature change of each raceway is an indicator of energy content of each output pathway. Higher temperature profile of $670^{\circ} \mathrm{C}$ contributes to higher gas yield and biomass conversion. The steam introduced with air increases the energy output by steam reforming and water gas shift reaction. Higher percent of catalyst of 50\% Dolomite enhances syngas quality by reducing the amount of tar. The optimum operating conditions that meet with energy requirements of the poultry house was achieved at chicken litter feeding rate of $0.7 \mathrm{~kg} / \mathrm{h}$ or equivalence ratio of 0.289 and temperature profile of $670^{\circ} \mathrm{C}$ and $50 \%$ of catalyst presence with gasifying agent of enriched air with steam that can change air temperature of $20^{\circ} \mathrm{C}$ in ten minutes. The gasifier provides total energy (surround and syngas) of $14.97 \mathrm{MJ} / \mathrm{h}$ and consumes of $1.85 \mathrm{MJ} / \mathrm{h}$. Whereas with gasifying agent of air only reduces the amount of energy consumed to $1.44 \mathrm{MJ} / \mathrm{h}$ and produces total energy of $13.34 \mathrm{MJ} / \mathrm{h}$. Calorific value of syngas achieved in both cases (air with steam and air only) are 5.75 and $5.11 \mathrm{MJ} / \mathrm{kg}$, respectively.

\section{INTRODUCTION}

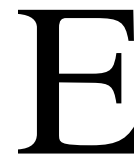

nvironmental condition inside poultry houses is the most important factor affecting broiler improvement and yield. With optimal environmental condition, the highest performance can be obtained with less feeding (Gornowicz et al., 2007). Air temperature should be maintained by using supplementary heating especially at low temperatures of weather. Most of poultry houses in Egypt use Liquefied Petroleum Gas (LPG) for warming purposes. The growth of domestic consumption of LPG is likely to increase after the year of 2000 and reduce exports to nearly 64 thousand tonnes by 2010. By 2015, Egypt became an importer of LPG by 26 thousand tonnes (UN, 2016 and OGJ, 
2016). On the other hand, nowadays the chicken litter disposal which contains wood chips, manure, feathers and spilled food is becoming a major problem, due to environmental and health concerns. The increment of these wastes accompanying the annual growth of $3.7 \%$ of poultry industry with total production of 851 thousand tonnes (FAO, 2013) is deteriorating waste handling. The fertilization practice of Tilapia ponds, depends on the application of chicken litter before farm stocking for ecosystem forming in the pond, was done in Egypt and all around the world for its stimulation of plankton growth in the pond (Knud-Hansen et al., 1993; Yi, 1998; Lin and Yi, 2003; Elnady et al., 2010). But this application strategy in last five years ago encountered a lot of problems such as some emergent dangerous diseases found in poultry house and affects severely the poultry production such as streptococcus which can infect or contaminate the fish ponds easily by contact. At the north area of Delta zone of Egypt, these diseases have a critical impact on human health that rises by lower water availability and quality. The other disposal method is land application which leads to pollute water resources due to leaching and runoffs (Hinton, 2000). For those reasons the demand on the poultry litter as an organic matter with highly nitrogen content source is reduced to be merely nothing. So the disposal of poultry litter is becoming a problem for human health and environmental concerns. However, chicken litter can be potentially converted into heat energy by combustion processor into gas by thermal gasification process to meet the energy requirements inside poultry houses. Gasification is a thermochemical conversion process of solid carbonaceous biomass (chicken litter) into a gaseous energy carrier called "syngas" or "product gas" in the presence of gasifying agents (Arena, 2012), such as atmospheric air (Mansaray et al., 1999), steam (Xiao et al., 2010a; Pauls et al., 2016), $\mathrm{CO}_{2}$ (Cheng et al., 2016) and enriched air with $\mathrm{O}_{2}$ (Nam et al., 2016) to produce a product gas of high heating value including $\mathrm{CH}_{4}, \mathrm{C}_{2} \mathrm{H}_{6}, \mathrm{H}_{2}, \mathrm{CO}, \mathrm{CO}_{2}$. However, (Barisano et al., 2016) use steam and oxygen mixture as a gasifying agent in fluidized bed gasifier, but there is no significance difference in comparison with oxygen enriched air. High moisture content in the chicken litter could stimulate the steam gasification generating a high percentage of hydrogen in the 
syngas $\left(\mathrm{H}_{2}+\mathrm{CO}\right)$. Fluidized bed gasification is the most advanced and extensive technique used for thermochemical conversion of different biomasses to energy with high economic and environmental issues (Xiao et al., 2010a). Gasifiers may be categorized as 'single stage' and 'multistage' arrangement (Hamel et al., 2007 and Xiao et al., 2010b). There are a lot of investigations on biomass conversion with and without catalysts, using different gasifying agents; temperatures and gasifiers design (Moustakas et al., 2005; Lemmens et al., 2007; Gomez et al., 2009; Mastellone et al., 2010). Char and tar are byproducts from gasification process. Char is a residual solid material from devolatization or pyrolysis of the carbonaceous in biomass. Tars are mixture of phenols, polycyclic aromatic hydrocarbons (PAHs) and heterocyclic compounds (Kim et al., 2013). The major defect of using the chicken litter, as a feedstock of auto-thermal gasification system, is it has lower ash melting temperature of $639^{\circ} \mathrm{C}$ (Taupe et al., 2016). There is an inverse relationship between the amount of tar and gasification temperature. The amount of tar realized can be eliminated by high temperature gasification $\left(700-1500^{\circ} \mathrm{C}\right.$ ) or by the use of catalytic gasification (Dolomite, $\mathrm{CaMg}$ $\left(\mathrm{CO}_{3}\right)_{2}$, Olivine, $\mathrm{MgFe}\left(\mathrm{SiO}_{4}\right)_{2}$ and commercial nickel, $\left.\mathrm{Ni}-\mathrm{Al}_{2} \mathrm{O}_{3}\right)$ with lower temperatures (400-670) (Hernandez et al., 2016; Thakkar et al., 2016). (Xiao et al., 2010a) investigate the presence of the catalysts in the steam gasification that significantly increases total gas, improves the gas quality and eliminates the tar content, but this field requires more investigations to assure the technical and economical availability. Gasifier design type also affects tar formation; quite high tar content realized by updraft gasifiers $10-150 \mathrm{~g} / \mathrm{m}^{3}$ for its lower heat transfer rate (Coutoa et al., 2013). However the downdraft gasifiers with higher operating temperature $\left(1100-1200^{\circ} \mathrm{C}\right)$ can reduce the amount of produced tar. Fluidized bed gasifier can overcome this limitation because of its higher heat transfer due to the fluidizing nature of gasifier's bed (Lasa $\boldsymbol{e t}$ al., 2011).

The aim of the present study is to investigate the optimum operating parameters of the manufactured fluidized bed gasifier for chicken litter conversion to syngas with higher calorific value for further exploitation in warming poultry houses. The effect of addition of different proportions of 
catalyst material to sand bed, three levels of temperatures, four different equivalence ratios and two different gasifying agents on the quality of syngas and energy output were considered in this investigation.

\section{MATERIALS AND METHODS}

The chicken litter feedstock was obtained directly from a poultry farm located at 12 Elezbah Elbaidah village, Elhamoul district, Kafr Elsheikh governorate during the period from December of 2015 to March of 2016 where wood chips were used for the main bedding. First of all, the chicken litter was collected and dried by hot air at $55^{\circ} \mathrm{C}$ with a Quonset greenhouse drying chamber with the dimensions of $1 \mathrm{~m}$ wide, $2 \mathrm{~m}$ long and $1 \mathrm{~m}$ height until to be less than $10.2 \%$ wb moisture content and bulk density of $389 \mathrm{~kg} / \mathrm{m}^{3}$. The processed litter was sized by screens between 20 and 35 meshes.

\section{Experimental setup}

The experimental system consists of five main parts: (1) fluidized bed gasifier reactor (2) litter biomass feeding section (3) air and steam supplying and preheating section (4) cleaning section and (5) thermal application section to the poultry house.

\section{Gasifier reactor}

Figure 1 shows the schematic diagram of the experimental gasifier. The reactor is constructed from two overlapped galvanic steel of $4 \mathrm{~mm}$ thick cylinders. The diameter of outer and inner cylinder is 47 and $40 \mathrm{~cm}$, respectively and $1.07 \mathrm{~m}$ height. The inner cylinder has a conical bottom with $30^{\circ}$ angle for optimum distribution between gas inlets through four installed jets and chicken litter (biomass). The catalyst bed is located at $70 \mathrm{~cm}$ height. Two cyclones are connected to the exit of the gasifier reactor to separate the solid particles (dust, ash and char) fleeing from the bed. The reactor and two cyclones are insulated with a flexible insulator sheets to reduce the heat loss from the system. The gas leaves the cyclones through an insulated pipe of $150 \mathrm{~mm}$ inside diameter to the ignition box in the poultry house. Liquefied petroleum gas (LPG) with a typical specific calorific value of $46.1 \mathrm{MJ} / \mathrm{kg}$, which consists of a mixture of propane $\left(\mathrm{C}_{3} \mathrm{H}_{8}\right)$ and butane $\left(\mathrm{C}_{4} \mathrm{H}_{10}\right)$ was used for gasifier heating. 


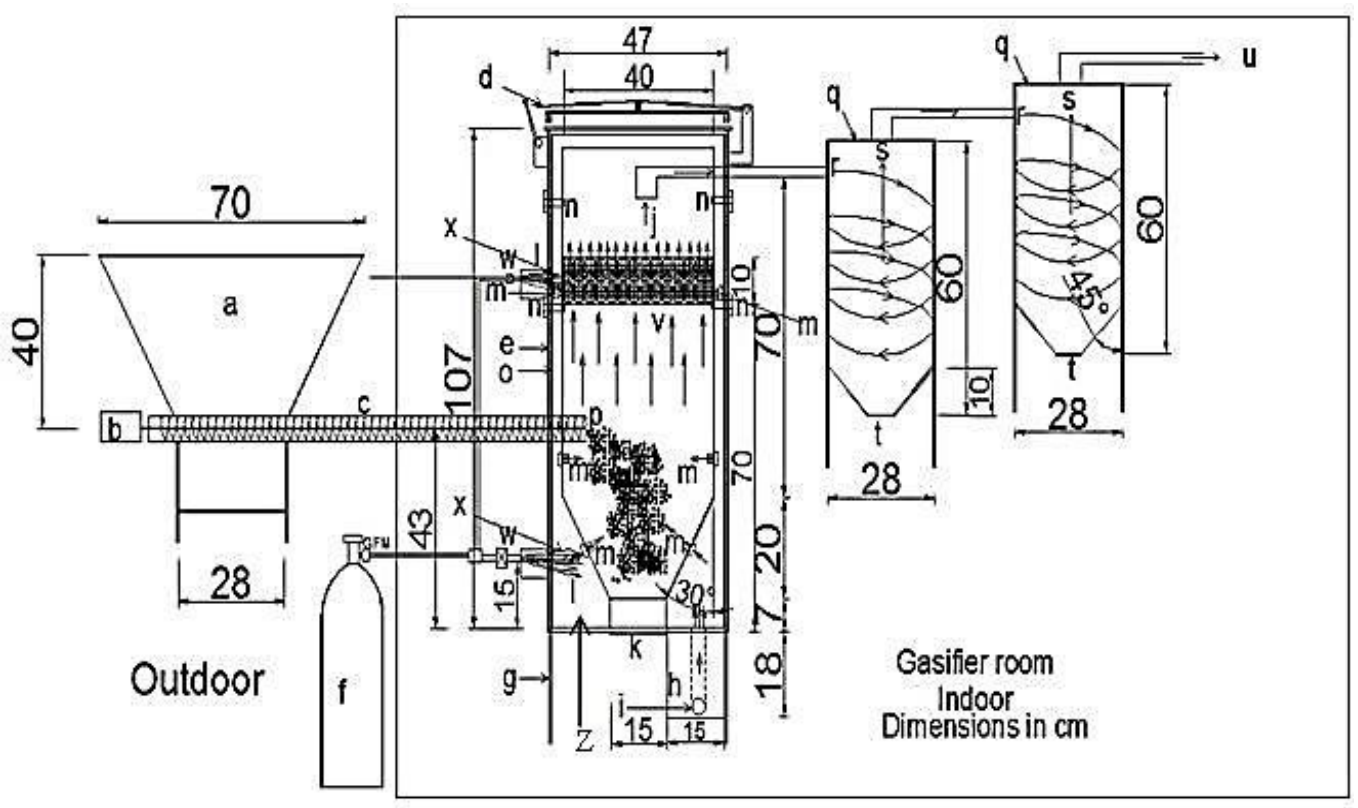

a-Feeder hopper; b-Direct current motor; c-Feeder's Auger;

d-Gasifier's Cover with lid latch, lid hinge and spring lid; e-Gasifier's body;

f-Liquefied petroleum gas; g-Gasifier's bearers;

h-Pre-heater chamber for inlet air; $\quad$ i-Air inlet tube (natural or mixed);

j-Gas outlet; l-Char outlet; I-Firing chamber; m-Gas jets;

n-Supports nails to connect the inside cylinder with the outer shelter;

o-Insulator wool ; p-Dried litter inlet to gasification chamber;

q-Cyclone for outlet gas filtration; r-Gas inlet to cyclone;

s-Filtered gas outlet; t-Char outlet

u-To poultry house warming system network; $\quad$ v-Catalyst bed;

w-Regulator valve; $\quad$ GFM-Gas flow meter; $\quad$ X-Ignition port;

Z-Combustion chamber.

Figure 1. Schematic drawing of the chicken litter gasification system

Two commercial LPG cylinders were used: one for gasifier reactor and the other for steam generator. Each one weighs $30 \mathrm{~kg}$ (filled) and $17.5 \mathrm{~kg}$ (empty). Two points of fire inlet to the space between the outer and inner shells of the gasifier. The LPG supply line was divided into two subways to the fire inlet points. The first fire inlet point is used for heating the catalyst bed chamber and the other is for fluidized bed reactor or 
gasification chamber. When the gasification condition is achieved by obtaining the predetermined temperature, the LPG supply is stopped and the preheat chamber acts as a simple wind box. Thermocouples of K-type were installed at five measuring points to illustrate the temperature profile inside the gasifier as shown in Figure 2. They are arranged regularly to be in the two chambers and at bed catalyst.

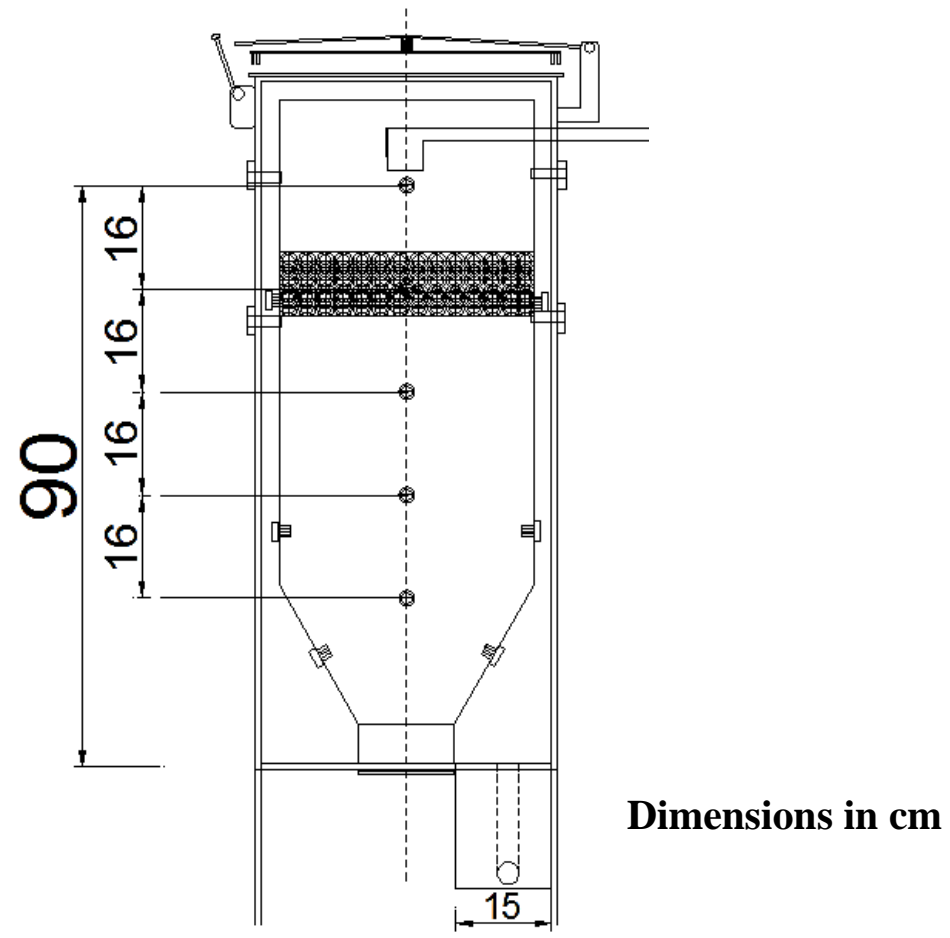

Figure 2. Thermocouples locations on the gasifier reactor

\section{Gasifying agents and chicken litter supplying}

Chicken litter biomass is introduced into the gasifier at height of $43 \mathrm{~cm}$ by screw-type feeder with $2.54 \mathrm{~cm}$ in diameter which feed a precise uniform amount of biomass continuously. The amount of biomass is controlled as revolutions per minute, RPM that is determined previously for each amount of each feeding rate. In countercurrent flow, the gasifying agent (natural air or enriched air with steam) is introduced from the bottom by air supplying system. The air supplying system consists of a blower (Three phase, $0.37 \mathrm{~kW}, 2850 \mathrm{RPM}, 50 \mathrm{~Hz}, 220 \mathrm{~V}$ and $13.4 \mathrm{~A}$, Italy), pressure gauge, gate valve for controlling the airflow rate, by-pass valve 
to prevent overheating of the electric motor and airflow meter. Before forced air inflowing to the gasifier reactor; it enters the preheat box located beneath the outer shell and flows toward the combustion chamber (the space between the conical bottom of the inner shell of gasifier and the outer shell). This flowed air can distribute the fire homogenously around the inner shell that raises the gasifier temperature swiftly. This process can heat the entered air also tremendously. After that the heated air enters the gasifier from the bottom through four jets positioned on the inner shell to litter chamber (m). The heated gasifying agent can decompose the chicken litter thermally, releasing primary raw gases. The released gases are getting through the catalyst bed at the second chamber accelerating the syngas reaction completion. The raw product gas (syngas) is redirected to two clarifying cyclones to separate the byproduct char. The steam is prepared by steam generator unit as shown in Figure 3 for air enriching at preheat chamber (h). Water feeding tank has a scale for water level measuring. The level reduction can determine the amount of steam consumed per hour.

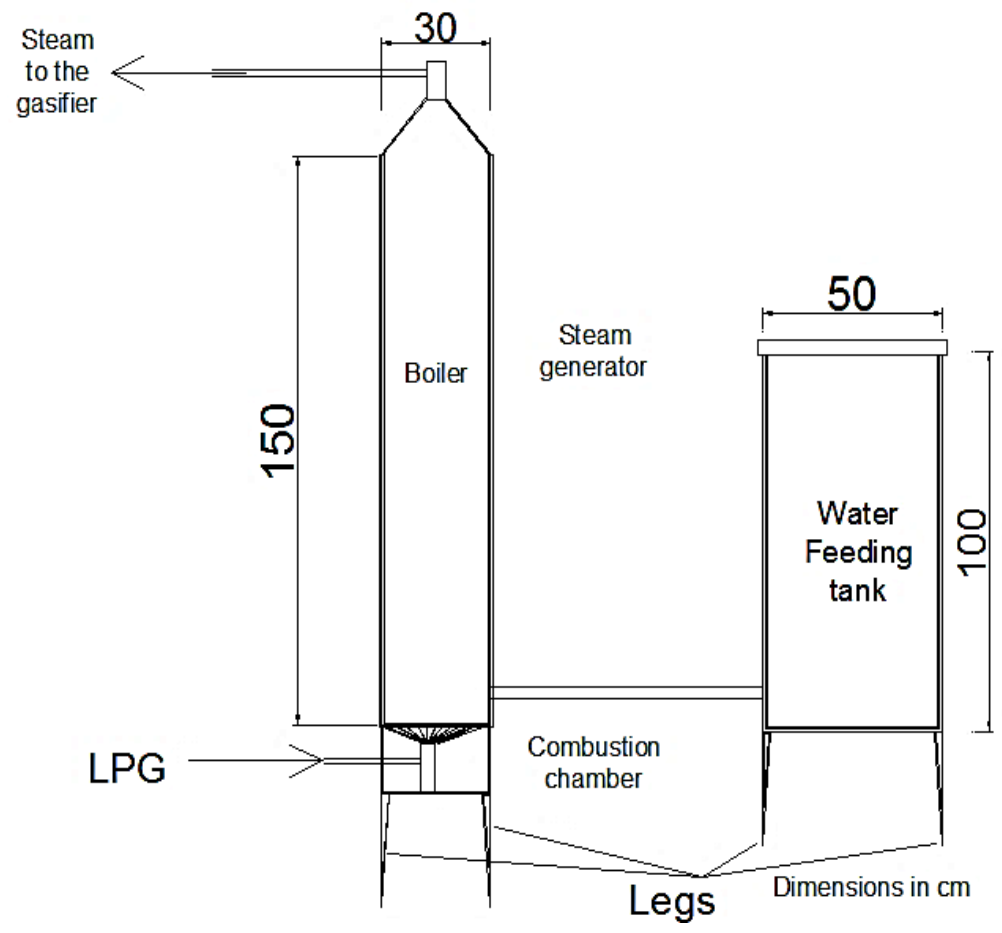

Figure 3. Schematic diagram of steam generator unit 
The whole system layout consists of two building structures, Figure 4. The first structure is the gasifier room which has one inlet and outlet for exchanging the surround air inside the room, suction fan $(\mathrm{m})$ installed at the end of the raceway 2 can force the air to move towards the air conduct (i) carrying the thermal energy realized inside the gasifier room to raceway 2 of the poultry house. The obtained syngas from the gasifier also transferred to poultry house (raceway 1 ) through the gas conduct (n) to an ignition box being released to the atmosphere. Thermal energy can be transferred by convection to whole the raceway 1 . Mass and energy balance analysis was considered during the experiment running as shown in Figure 5.
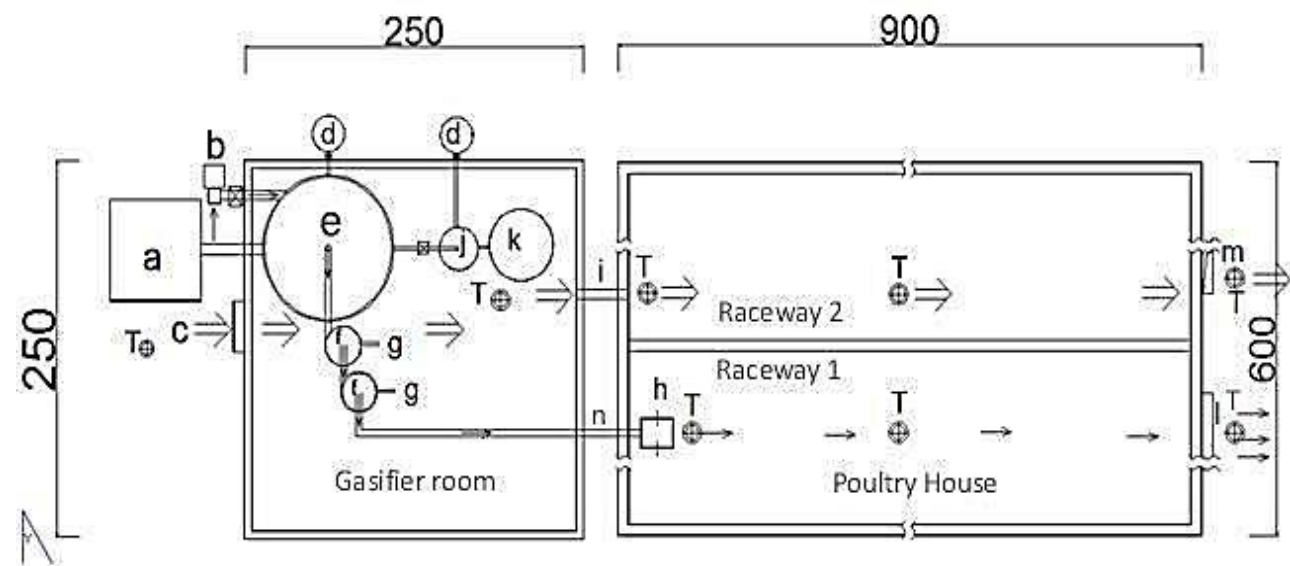

Dimensions in $\mathrm{cm}$

a-Chicken litter feeder; b-Air blower with a gate valve; c-Window;

d-Liquefied petroleum gas; e-Gasifier; f-Cyclone for outlet gas filtration;

g-Char outlet; h-Ignition box; i-Air duct; j-Steam generator;

k-Water feeding tank l-Window; m-Suction fan; n-Syngas duct;

T-Thermocouple locations.

Single arrow is syngas path Duplicate arrow is heated air path from the gasifier reactor surrounding

Figure 4. Whole system layout

\section{Experimental procedure}

The group of experiments were done by different feeding rates of chicken litter biomass and air (natural air or enriched air with steam), as shown in Table 1. The biomass feed rates ranged from 0.62 to $1.0 \mathrm{~kg} / \mathrm{h}$, and airflow rate is kept constant at $0.809 \mathrm{~kg} / \mathrm{h}$. For equivalence ratio calculations, 
theoretical air or stoichiometric air measuring is important for the determination of the nature of the burning process. The stoichiometric ratio of chicken litter was determined by using equation 1 (Johari et al., 2011) at the laboratory of Department of Chemistry, Faculty of Science, Kafrelsheikh University. The result obtained is four mass unit of air to one mass unit of chicken litter, and by substituting this stoichiometric ratio in equation 2 gives four representative experimental conditions of equivalence ratios of $0.326,0.289,0.227$ and 0.202 .

Volume of theoretical air required:

$\mathrm{A}_{0}=4.76 \times 22.4\left(\frac{\mathrm{gC}}{12 \mathrm{~g} / \mathrm{mol}}+\frac{\mathrm{gH}}{4 \mathrm{~g} / \mathrm{mol}}-\frac{\mathrm{gO}}{32 \mathrm{~g} / \mathrm{mol}}+\frac{\mathrm{gS}}{32 \mathrm{~g} / \mathrm{mol}}\right) \quad$ Eqn 1 $\mathrm{A}_{0}=8.88 \mathrm{C}+26.66 \mathrm{H}-3.330+3.33 \mathrm{~S}$ by substituting the values of Table 2 obtaining

$$
\mathrm{A}_{0}=\frac{394.6 \mathrm{~L} \text { air }}{100 \mathrm{~g} \text { Chicken litter }} \cong 4: 1
$$

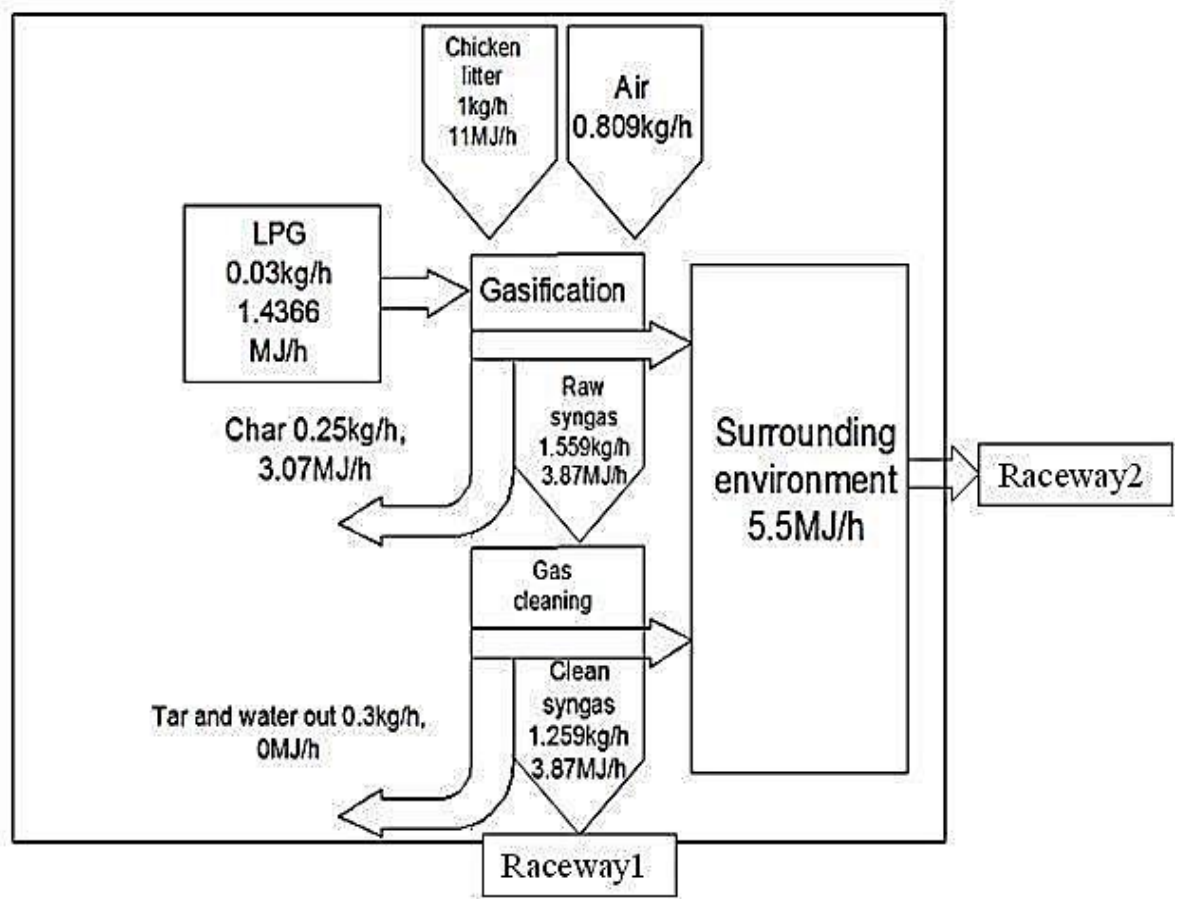

Figure 5. Flowchart of mass and energy balances of gasification process at low heating value of chicken litter 
Table 1. Equivalence ratio (ER) under investigation for natural air and enriched air with steam gasification

\begin{tabular}{|l|c|c|c|c|c|}
\hline \multirow{2}{*}{ Parameter } & \multirow{2}{*}{ Startup } & \multicolumn{4}{|c|}{ Experimental cases } \\
\cline { 3 - 6 } & & $\mathbf{1}$ & $\mathbf{2}$ & $\mathbf{3}$ & $\mathbf{4}$ \\
\hline $\begin{array}{l}\text { Chicken litter } \\
\text { feeding rate, } \mathrm{kg} / \mathrm{h}\end{array}$ & 2.0 & 0.62 & 0.70 & 0.89 & 1.0 \\
\hline Natural air, kg/h & 12.56 & 0.809 & 0.809 & 0.809 & 0.809 \\
\hline $\begin{array}{l}\text { Equivalence } \\
\text { ratio, decimal }\end{array}$ & 1.57 & 0.326 & 0.289 & 0.227 & 0.202 \\
\hline Parameter & Startup & \multicolumn{5}{|c|}{ Experimental cases } \\
\cline { 2 - 6 } & $\mathbf{5}$ & $\mathbf{6}$ & $\mathbf{7}$ & $\mathbf{8}$ \\
\hline $\begin{array}{l}\text { Chicken litter } \\
\text { feeding rate, } \mathrm{kg} / \mathrm{h}\end{array}$ & 2.0 & 0.62 & 0.70 & 0.89 & 1.0 \\
\hline $\begin{array}{l}\text { Enriched air with } \\
\text { steam } \\
\text { (air+steam), kg/h }\end{array}$ & $12.56+0.12$ & $0.809+0.12$ & $0.809+0.12$ & $0.809+0.12$ & $0.809+0.12$ \\
\hline $\begin{array}{l}\text { Equivalence } \\
\text { ratio, decimal }\end{array}$ & 1.57 & 0.326 & 0.289 & 0.227 & 0.202 \\
\hline
\end{tabular}

For gasifier initialization, the equivalence ratios are high as 1.570 and 1.585 for natural air and enriched air with steam gasification, respectively. During the first hour of this process, the amount of chicken litter consumed is $2 \mathrm{~kg}$. The catalyst bed temperature can be achieved and kept constant by adjusting the valve controlling the flow of LPG to the catalyst chamber. The temperature of litter chamber is under investigation for gasification process evolutionary. Three levels of treating temperature were considered of 430,560 and $670^{\circ} \mathrm{C}$. The flow rate of natural air and enriched air with steam is kept almost constant in all the experiments at $0.809 \mathrm{~kg} / \mathrm{h}$ to achieve the same gas residence time for both cases and to maintain the fluidization of the chicken litter bed in bubbling regime. However, the chicken litter feeding rate varied from 0.62 to $1.0 \mathrm{~kg} / \mathrm{h}$.

$$
\mathrm{ER}=\frac{\text { Actual air chicken litter ratio }}{\text { Stoichiometric air chicken litter ratio }} \quad \text { Eqn } 2
$$

Raw Dolomite, obtained from the Geology Department, Faculty of Science, Kafrelsheikh University, is added separately to the coarse sand bed $(1-2 \mathrm{~mm})$ in different proportions $(20,30$ and $50 \%)$ to determine the optimum combination of sand bed material with the catalyst at different levels of reactor temperature from 430 to $650^{\circ} \mathrm{C}$. An energy balance was 
carried out to determine the gasification process performance at different: equivalence ratios, proportions of catalyst mixed with sand, gasifying agents and temperatures. Indoor poultry house temperature at raceways 1 and 2 is controlled by the heat flux coming from gasifier room $\left(Q_{\text {gas }}\right)$. Resulting heat energy in the poultry house is owed to the summation of heat loss from: walls $\left(Q_{\text {con }}\right)$, windows, door and roof $\left(Q_{w}\right)$, air infiltration $\left(Q_{\text {inf }}\right)$ and ventilation $\left(Q_{\text {vent }}\right)$ and heat generated by chickens $\left(Q_{m}\right)$ (Xin et al., 2001). The energy balance through equations 3, 4 and 5 (modified after Dounis et al., 1995) of the room air temperature difference $\mathrm{dT}_{a}$, air mass $\mathrm{m}_{a}$ and air specific heat $\mathrm{c}_{a}$ is written as:

$$
\mathrm{Q}_{\text {gas }}=\mathrm{m}_{\mathrm{a}} \mathrm{c}_{\mathrm{a}} \mathrm{dT}_{\mathrm{a}}=\mathrm{Q}_{\mathrm{m}}-\mathrm{Q}_{\mathrm{L}}
$$

Eqn 3

Heat loss $Q_{L}$ from structural elements can be calculated by using the following equation during winter season:

$$
\mathrm{Q}_{\mathrm{L}}=\mathrm{A} . \Delta \mathrm{t} . \sum \mathrm{U}=\mathrm{Q}_{\mathrm{con}}+\mathrm{Q}_{\mathrm{w}}+\mathrm{Q}_{\mathrm{inf}}+\mathrm{Q}_{\mathrm{vent}} \quad \text { Eqn } 4
$$

Where $\sum U$ is the coefficient of conductance of structural elements $\left(\mathrm{Wm}^{-2} \mathrm{~K}^{-1}\right), \mathrm{A}$ is the surface area of structural elements in $\mathrm{m}^{2}, \Delta \mathrm{t}=\left(\mathrm{t}_{i}-\right.$ $t_{o}$ ) is the difference between inside $t_{i}$ and outside $t_{o}$ temperature of poultry house $(\mathrm{K})$.

Total thermal conductance coefficient (U) can be calculated by using the following equation:

$$
U=\frac{1}{\frac{1}{f_{i}}+\sum_{i=1}^{n} \frac{d_{i}}{k_{i}}+\frac{1}{f_{o}}}
$$

Where $f_{i}$ and $f_{o}$ are the surface coefficients of inside and outside thermal conductance of structural elements $\left(\mathrm{Wm}^{-2} \mathrm{~K}^{-1}\right), \mathrm{d}$ and $\mathrm{k}$ are width of structural elements in $\mathrm{m}$ and thermal conductivity in $\mathrm{Wm}^{-1} \mathrm{~K}^{-1}$, respectively. The stocking density of chicken in raceway 1 and raceway 2 was $0.05 \mathrm{~m}^{2}$ per chicken. 
Table 2. Proximate and ultimate analysis of chicken litter

\begin{tabular}{|l|l|}
\hline Ultimate analysis (wt.\% dry) & 4.83 \\
\hline Nitrogen & 39.59 \\
\hline Carbon & 5.17 \\
\hline Hydrogen & 30.53 \\
\hline Oxygen & 0.98 \\
\hline Sulfur & 53.16 \\
\hline Proximate analysis (wt.\% dry) & 15.8 \\
\hline Volatiles & 21.65 \\
\hline Fixed carbon & 12.99 \\
\hline Ash content at $550^{\circ} \mathrm{C}$ & 11.42 \\
\hline High heating value, $\mathrm{HHV}(\mathrm{MJ} / \mathrm{kg})$ as received & 30.16 \\
\hline Low heating value, $\mathrm{LHV}(\mathrm{MJ} / \mathrm{kg})$ as received & \\
\hline Moisture (wt.\%) as received &
\end{tabular}

\section{RESULTS AND DISCUSSION}

\section{Microclimatic conditions}

Figure 6 shows the suitable time for experimentation is from 12:00AM to 7:00AM because the outside (ambient) air temperature is almost constant at $12^{\circ} \mathrm{C}$ during the period from the $2^{\text {nd }}$ to the $18^{\text {th }}$ of January of 2016 and $11^{\circ} \mathrm{C}$ during the period from the $19^{\text {th }}$ of January to the $22^{\text {nd }}$ of February of the same year. Thermal energy released to the surround in the gasifier room is flowed to raceway 2 to be measurable as a temperature indicator of the gasification process. Syngas energy also measured in raceway 1 as thermal energy used for warming in this raceway. Figure 7 shows the hourly deficit thermal energy of $1858.08 \mathrm{~kJ} / \mathrm{h}$ during the period from 12:00AM to 7:00AM for temperature difference of $11^{\circ} \mathrm{C}$ between the desired air temperature of inside of $23^{\circ} \mathrm{C}$ and outside air temperature of $12^{\circ} \mathrm{C}$. Further daytime, the hourly net thermal energy starts to increase to be excess from 9:00AM to 7:00PM. This means that, at this period, the thermal energy will be accumulated and air temperature inside will increase to be above $23^{\circ} \mathrm{C}$. From Figure 7, it's observed that the poultry house needs for the thermal energy supplying during the period from 7:30PM to nearly 9:00AM. But the extreme requirement starts from 11:00PM to 7:00AM. The ventilation rate of raceway 2 was calculated according to the moisture production by chicks and air supply conditions. 
The psychrometric chart was employed to determine air supply conditions to meet with these energy requirements. The gasifier was adjusted primarily to investigate all the operating parameters to elucidate the gasifier performance under these duties. The experiment was done at steady state conditions which is from 12:00AM to 7:00AM (the air temperature difference between inside and outside is $11^{\circ} \mathrm{C}$ for seven hours).

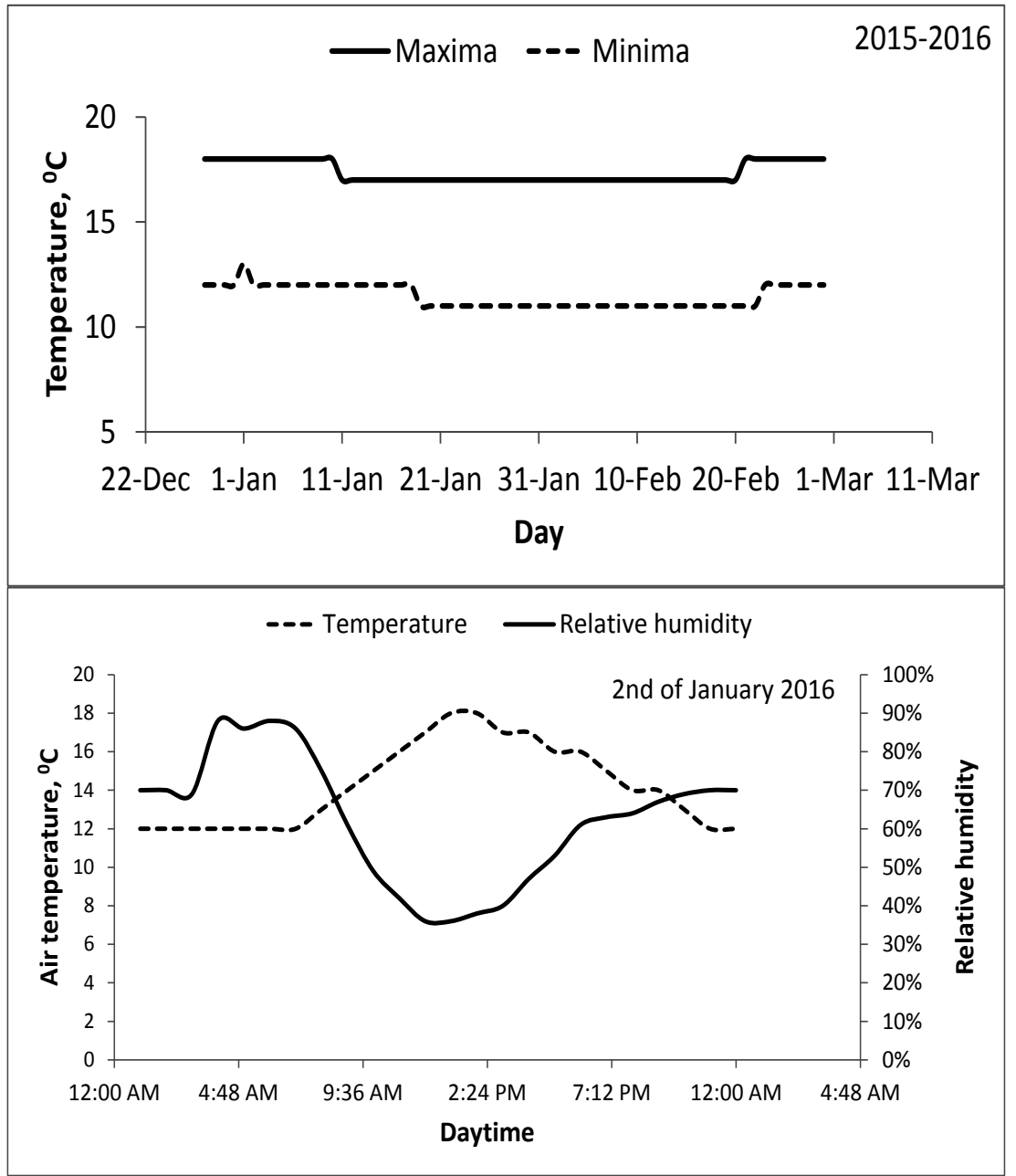

Figure 6. Weather conditions during the experimental run

To define the state points on the chart, see Figure 8. "Desired" is the poultry house temperature of $23^{\circ} \mathrm{C}$ and $70 \%$ relative humidity to be 
maintained. "Outside" is the environmental air temperature of $12^{\circ} \mathrm{C}$ and air relative humidity of $90 \%$. "Actual" is the measured air characteristics of poultry house temperature of $16^{\circ} \mathrm{C}$ and $87 \%$ relative humidity. "Supply $1 "$ is the applied air characteristics if all the outlet air from the poultry house is recirculated, and "Supply 2" if there is no circulation and the air inlet is totally from the outside environment. "Room ratio line" was calculated by dividing the generated heat from chicks of $8424.5 \mathrm{~kJ} / \mathrm{h}$ by the sensible heat loss of $1858.08 \mathrm{~kJ} / \mathrm{h}$, which gives ratio of 0.82 that can be drawn on the protractor, top segment, on the chart and transfer this line onto the chart so that it passes though the point "Desired", a horizontal line from the point "Actual" to the right hand side of the chart can determine the point of "Supply 1" by intersecting the "Room ratio line". The same process can be done with the state point of "Outside" to determine the point of "Supply 3". The state point of "M" is determined by measuring the line drawn of "Actual" - "Outside" and multiplies this by the mixing ratio of 0.5 , a mixture of $50 \%$ of natural air and outlet air from the poultry house, so the point $\mathrm{M}$ is positioned in the center of the line and its psychrometric characteristics is $14.5^{\circ} \mathrm{C}$ and $88 \% \mathrm{RH}$. The point of "Supply 2" can be obtained by the same process discussed above. The psychrometric characteristics achieved of the first "Supply 1", second "Supply 2" and third "Supply 3" case of air application are: $\left(48^{\circ} \mathrm{C}, 14 \%\right.$ $\mathrm{RH}, 0.00977 \mathrm{~kg}$ vapor $/ \mathrm{kg}$ dry air), ( $56.5^{\circ} \mathrm{C}, 8.9 \% \mathrm{RH}, 0.00940 \mathrm{~kg}$ vapor $/ \mathrm{kg}$ dry air) and $\left(65^{\circ} \mathrm{C}, 5 \% \mathrm{RH}, 0.00811 \mathrm{~kg}\right.$ vapor $/ \mathrm{kg}$ dry air), respectively. The calculated airflow rate is of $57.207 \mathrm{~kg} / \mathrm{h}$. The amount of energy applied to the air from the outside is $3112.06 \mathrm{~kJ} / \mathrm{h}$, whereas the amount of energy is reduced, when the air is of $50 \%$ mixture, to $2506.24 \mathrm{~kJ} / \mathrm{h}$ and $1858.08 \mathrm{~kJ} / \mathrm{h}$ when there is no air exchange. In this investigation the third case of air supplying "Supply 3" is applied. So the sensible energy required, for both raceways 1 and 2 , are $3112.061 \mathrm{~kJ} / \mathrm{h}$ and there is no latent energy will be applied.

\section{Thermal gasification of chicken litter}

In this study; different proportions of catalytic steam and air gasification under different heating temperatures of chicken litter have been investigated by a series of experiments. The effects of treating temperature $\left(430,560\right.$ and $\left.670^{\circ} \mathrm{C}\right)$, catalyst presence percent $(20,30$ and 
$50 \%$ ) in the coarse sand bed (1-2mm), gasifying agent (air only and air with steam) and equivalence ratio $(0.326(0.62 \mathrm{~kg} / \mathrm{h}), 0.289(0.70 \mathrm{~kg} / \mathrm{h})$, $0.227(0.89 \mathrm{~kg} / \mathrm{h})$ and $0.202(1.00 \mathrm{~kg} / \mathrm{h}))$ on syngas energy and energy released to the surround.

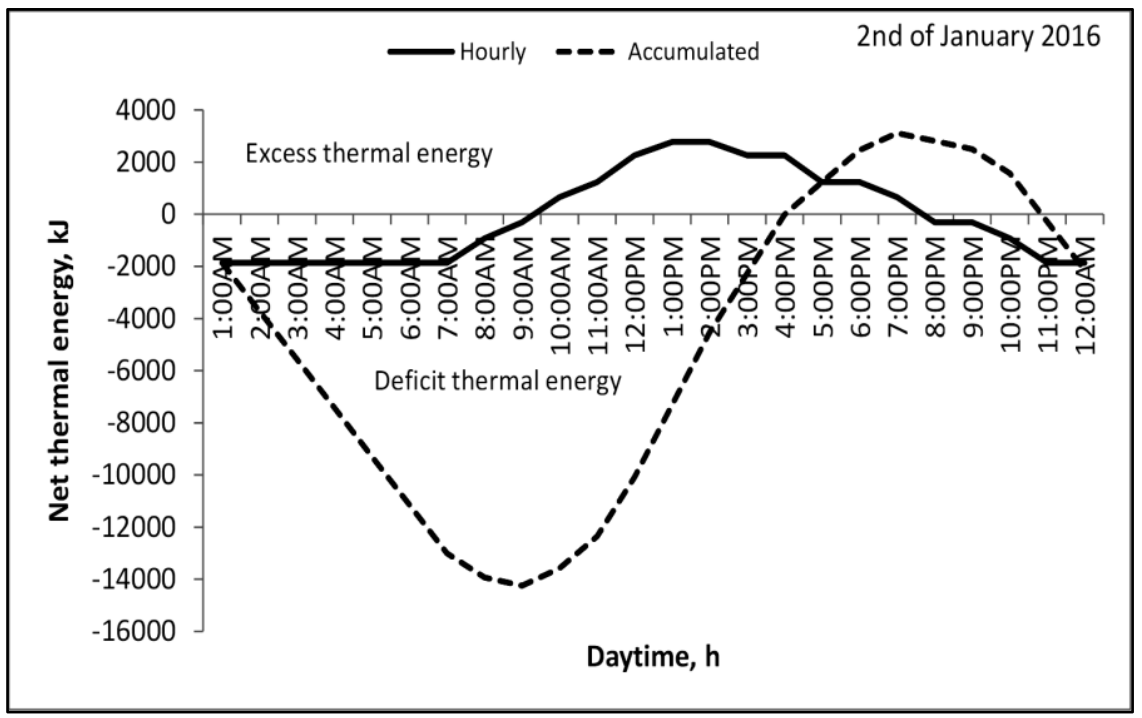

Figure 7. Net thermal energy at each daytime hour at raceway 2 without any modifications

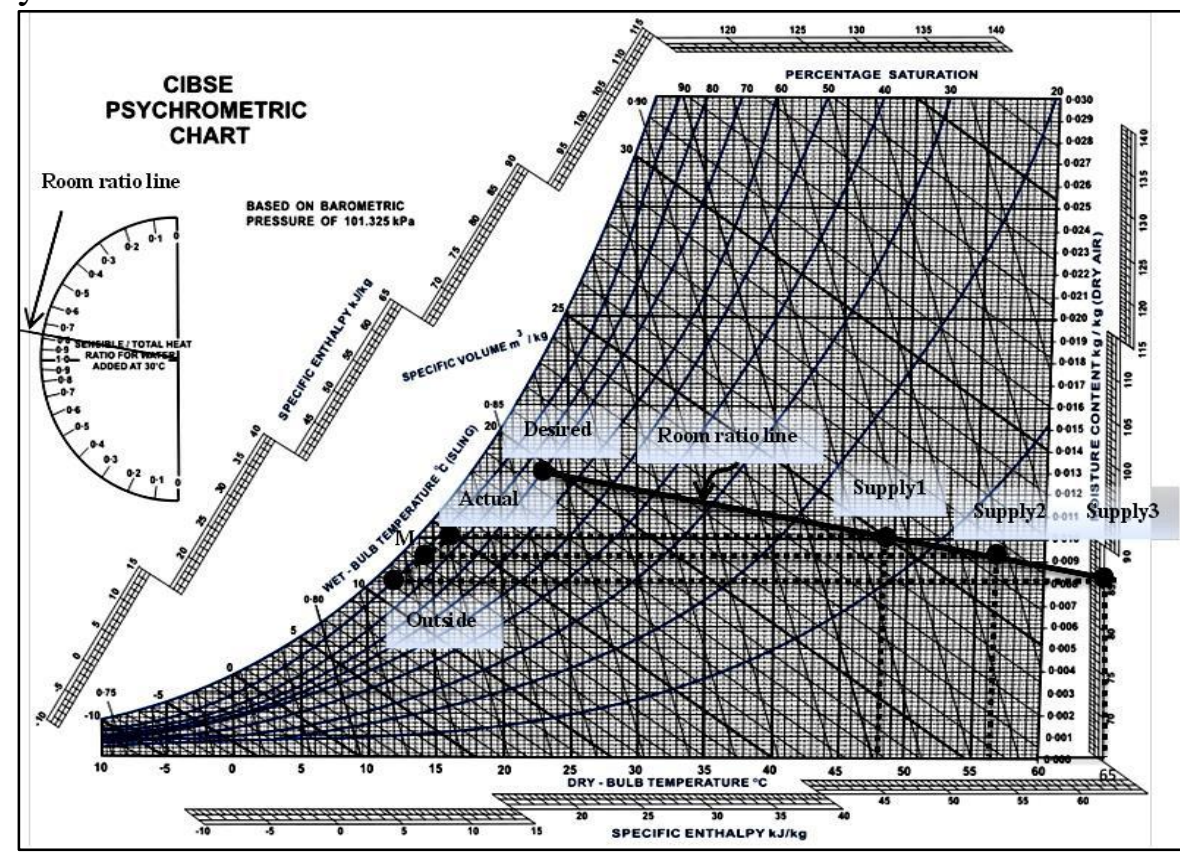

Figure 8. Supply air characteristics determination by the psychrometric chart 


\section{Effect of treating temperature}

The reaction temperature inside the litter gasification chamber is the most important factor for the overall gasification process. Figure 9A shows the temperature profiles in the gasifier. Chicken litter introduced to the gasifier decomposes thermally based on the temperature of circumferences. It was observed as the temperature profile of the gasifier increases, air temperature of raceway 1 and raceway 2 increases subsequently due to the higher energy obtained from the thermal decomposition of chicken litter, Figure 9B. As equivalence ratio decreases from 0.326 to 0.289 or the chicken litter induced increases from 0.62 to $0.70 \mathrm{~kg} / \mathrm{h}$, air temperatures inside the raceway 1 changes from 1.6 , 2.5 and $7.0^{\circ} \mathrm{C}$ to $3.7,7.0$ and $10.8^{\circ} \mathrm{C}$ in ten minutes at treating temperatures of 430,560 and $670^{\circ} \mathrm{C}$, respectively at $50 \%$ of catalyst presence percent and gasifying agent of air only. The same trend was obtained at raceway 2. This is because the low feed rate of biomass against the gasifying agent flow rate yield less combustion heat and hot product gas; whereas higher changes of air temperatures were obtained at equivalence ratios of 0.289 and 0.227 for higher homogenous distribution between the two solid and air reactants. The gasifying agent of air with steam has higher effect on air temperature changes of $20^{\circ} \mathrm{C}$ in ten minutes at equivalence ratio of 0.289 and treating temperature of $670^{\circ} \mathrm{C}$. The chicken litter introduced experiences preheating and combustion inside the gasifier and it turns into combustion gases and then take part in the gasification process. In the presence of steam, the vapor react with carbon monoxide releases more hydrogen gas that acts as a heat transfer medium of the new introduced litter that generates more thermal energy from the biomass. The relationship between litter expansion in the gasifier reactor and gasification progress is notable until certain limit that achieved at equivalence ratio of 0.289 .

\section{Released and consumed energy}

In order to investigate the conversion details of this thermochemical process of the gasifier, the amount of energy consumed and released of each treatment was plotted in Figures 10 and 11. Energy used for gasifier and gasifies agents (air only or air with steam) temperature conditioning is considered as a consumed energy. The energy obtained from the syngas can be calculated based on air temperature changes inside raceway 1 as 
illustrated above with time in Figure 9, and the energy emitted to surround can also be calculated according to air temperature difference inside raceway 2 .

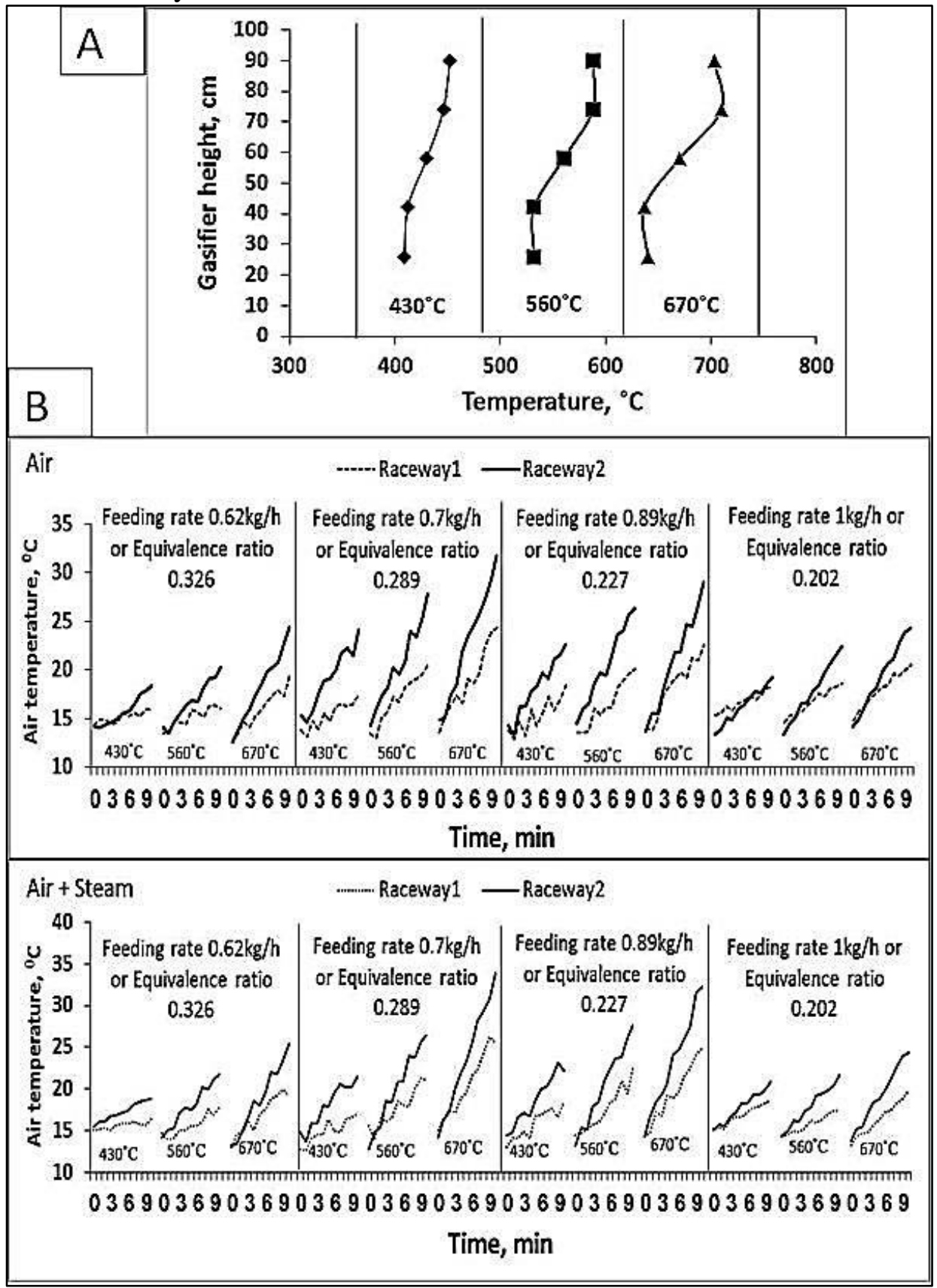

Figure 9. Vertical temperature distribution of the gasifier (A) and air temperatures changes inside the poultry house at raceway 1 and raceway 2 (B) 
Figures 10 and 11 show the amount of energy magnified when using thermal gasification of chicken litter as an alternative source of energy. Total energy obtained, summation of energy of syngas and the energy released to surround, is about 9.28 times higher than the consumed energy. Maximum total energy of $14.97 \mathrm{MJ} / \mathrm{h}$ obtained was at treating temperature of $670^{\circ} \mathrm{C}$, equivalence ratio of $0.289,50 \%$ of bed catalyst, and the gasifying agent of air with steam, that magnifies thermal energy with only 8.08 times due to higher energy consumed of $1.85 \mathrm{MJ} / \mathrm{h}$ for steam generation and gasifier conditioning at $670^{\circ} \mathrm{C}$. Whereas the maximum magnification of thermal energy is 9.28 times could be obtained at treating temperature of $670^{\circ} \mathrm{C}$, equivalence ratio of 0.289 , $50 \%$ of bed catalyst, and the gasifying agent of air only.

\section{Effect of equivalence ratio and catalyst presence percent}

Equivalence ratio (ER) is an important parameter that determines the amount of thermal energy released during the exothermic reactions of chicken litter bed. This run of experiments was done to define the optimum equivalence ratio with the gasifier under investigation. Gasifying agent flow rate is kept constant during the experiment at $0.809 \mathrm{~kg} / \mathrm{h}$. For this reason chicken litter feeding rate is a limiting determinant of equivalence ratio magnitude. Higher values of ER towards the reaction to combustion process due to the reduction in chicken litter feeding rate against the heated airflow rate as well as the gas outlet temperature increases, similar trends were also obtained by (Kim $\boldsymbol{e t}$ al., 2013; Thakkar et al., 2016). The increase in ER from 0.202 to 0.289 increases the air temperature inside the gasifier due to the enhancement of chicken litter mixing with the heated air that progresses heat transfer in the reaction zone. Larger ER of 0.326 or lower chicken litter feed rate of $0.62 \mathrm{~kg} / \mathrm{h}$ decreases enough the bed provided for gasification process. As chicken litter feeding rate increases from 0.62 to $0.70 \mathrm{~kg} / \mathrm{h}$, the released energy increases tremendously in all experimental cases with an average of $55.3 \%$, Figure 12. At low treating temperature of $430^{\circ} \mathrm{C}$, the effect of catalyst bed percent has no effect on the released energy. However at higher treating temperatures of 560 and $670^{\circ} \mathrm{C}$ in steam gasification process with the highest presence percent of the catalyst (50\% Dolomite) causes a significant increase of syngas yield more than $36 \%$ of energy output and low light tar was observed in the cyclones (cold traps). The energy output increases due to higher formation of hydrogen in the 
product gas. These results indicate that the catalyst promotes tar cracking and steam reforming. Therefore, it improves the quality of syngas and diminishes the tar content in the product gas. These results are in agreement with (Xiao et al., 2010a).

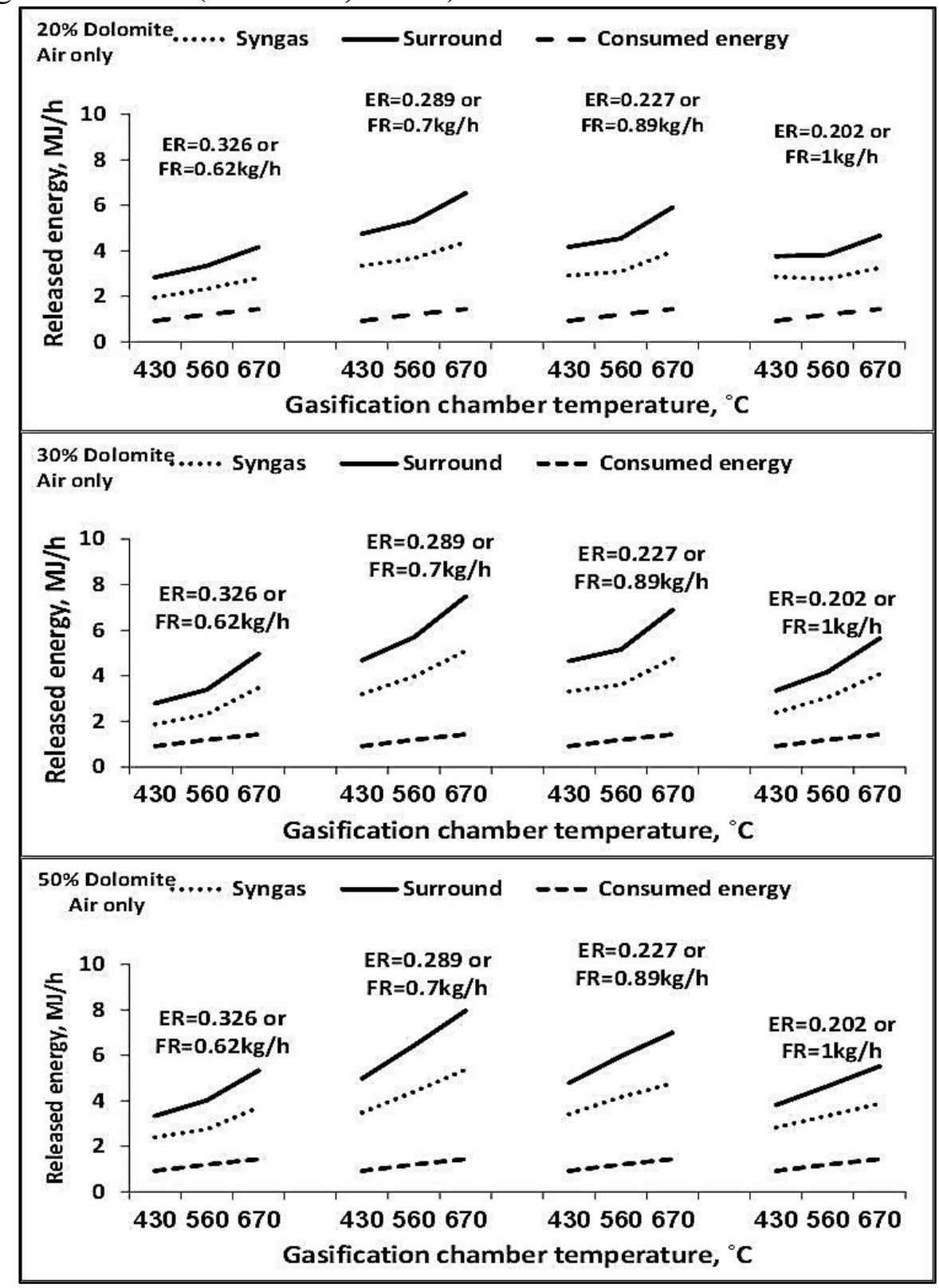

Figure 10. Energy released and consumed for chicken litter gasification of gasifying agent of air only, where; ER is the equivalence ratio and FR is the feeding rate 


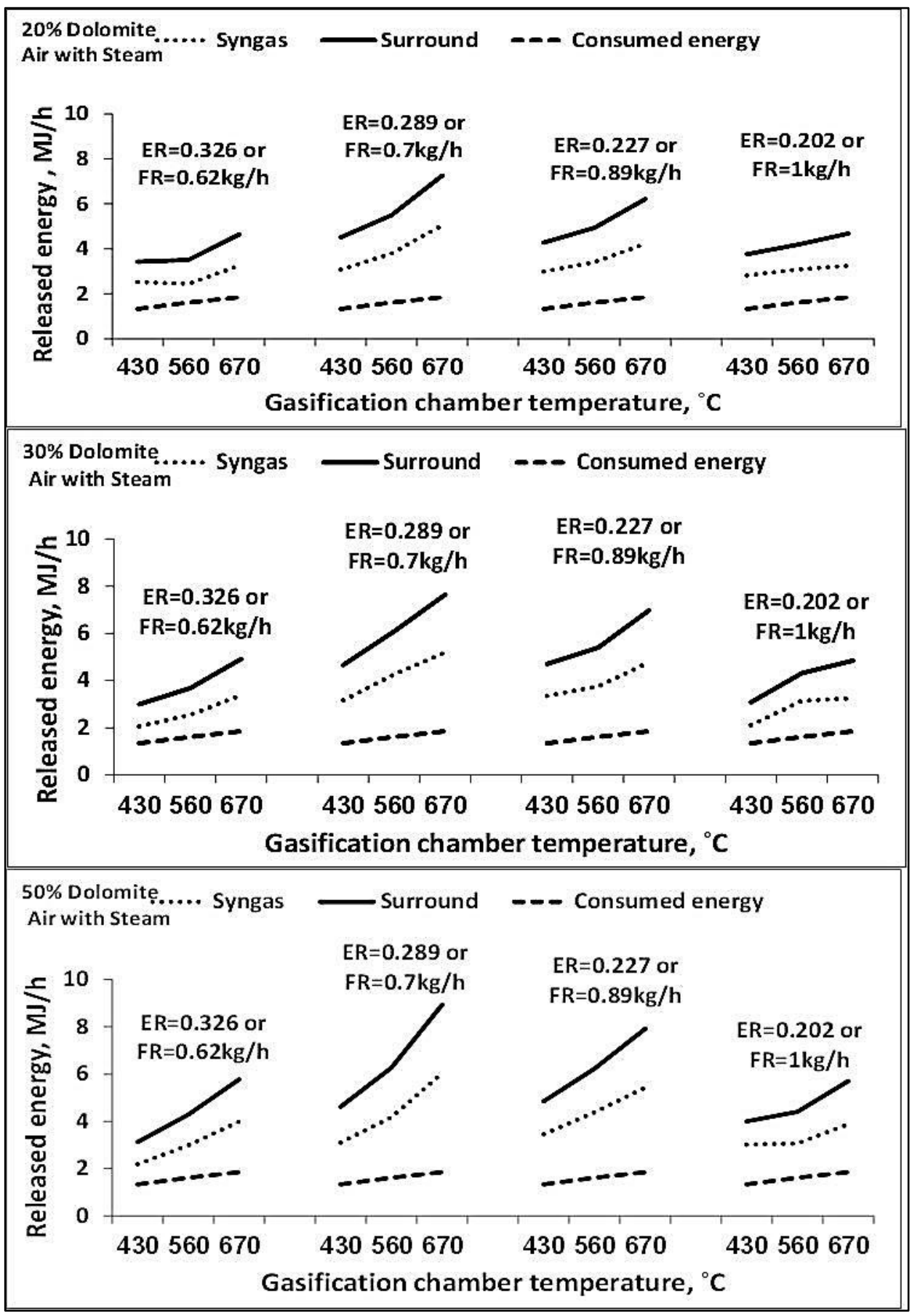

Figure 11. Energy released and consumed for chicken litter gasification of gasifying agent of air with steam, where; ER is the equivalence ratio and FR is the feeding rate 


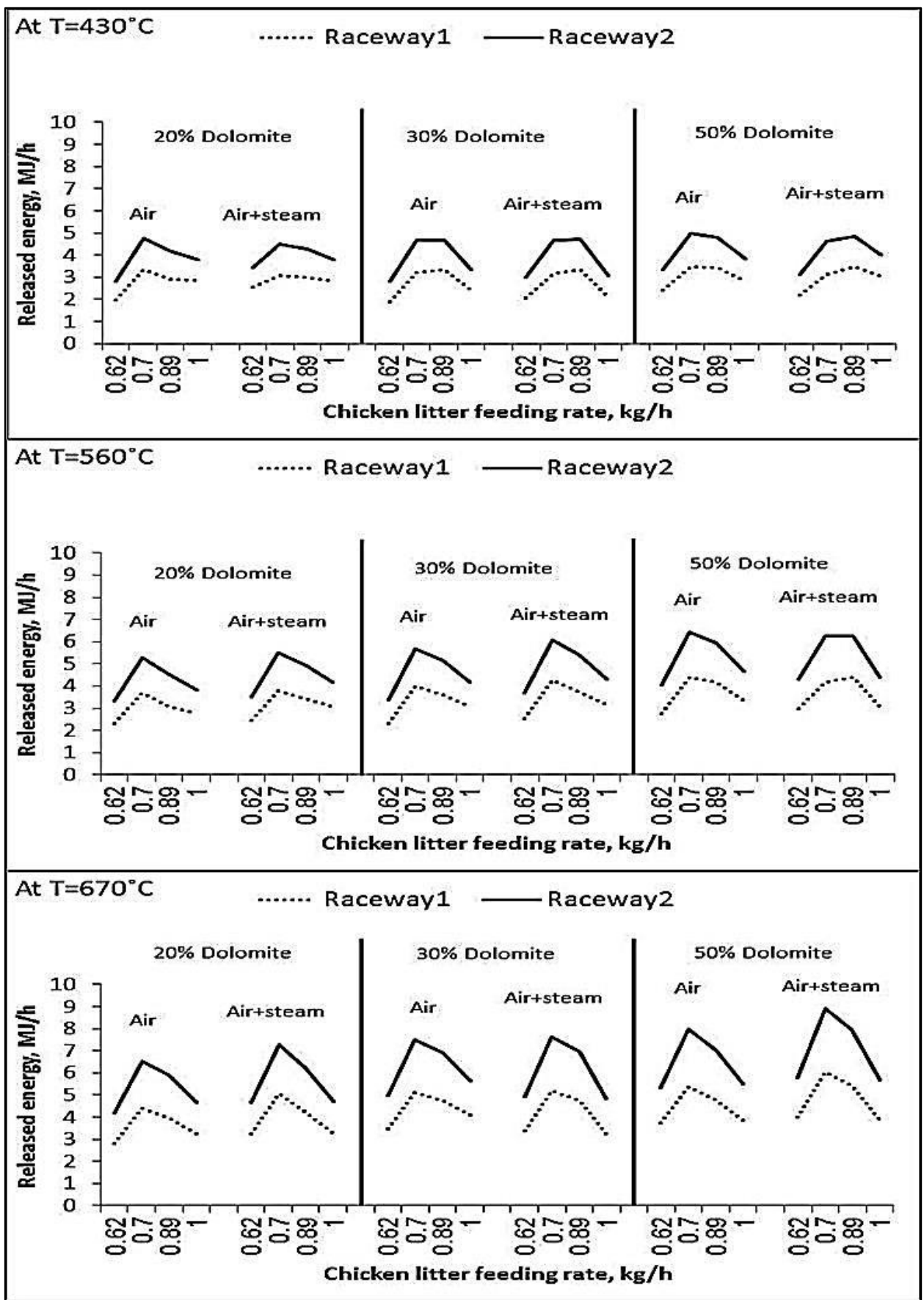

Figure 12. The effect of chicken litter feeding rate, Dolomite percent in the catalytic bed and gasifying agent on energy released to raceway 1 and raceway 2 of the poultry house under different levels of gasification chamber temperature 


\section{CONCLUSIONS}

Thermal gasification technique is a reliable process for energy releasing from chicken litter at low temperatures used for poultry houses warming. Chicken litter feed rates and air were controlled the change of equivalence ratios and vary the internal conditions. Air temperature changes as energy output of thermal gasification was measured in duration time of ten minutes. Optimum equivalence ratio achieved of 0.289 can raise air temperature from 14.88 and $13.6^{\circ} \mathrm{C}$ to 31.66 and $24.4^{\circ} \mathrm{C}$ for raceway 1 and raceway 2 , respectively, at ideal treating temperature of $670^{\circ} \mathrm{C}$ and gasifying agent of air only. However when air and steam mixture is used as a gasifying agent increases air temperature inside the raceways but consumes more energy than when air only used as a gasifying agent. Raw Dolomite is used as a catalyst which is necessary for gasification with low air temperature that reduces the amount of tar found in cyclones and raises the calorific value of syngas. As presence percent of Dolomite raises in the sand bed from 30 to $50 \%$ with equivalence ratio of 0.289 and temperature profile of $670^{\circ} \mathrm{C}$, the calorific value of syngas increases from 4.17 to $5.12 \mathrm{MJ} / \mathrm{kg}$. However when the steam is used, the calorific value of syngas increases to $5.75 \mathrm{MJ} / \mathrm{kg}$. Thermal energy emitted to the surround was exploited by replaced continuously by natural air and directed to raceway 2. The amount of this energy exceeds about $48 \%$ of energy content of the product gas. For further investigations, the fluidized bed gasifier reactor needs some studies about the relationship between fluidization number, air pressure drop and maximum chicken litter feeding rate and airflow rate can execute with optimum achieved equivalence ratio in this study of 0.289 .

\section{REFERENCES}

Arena, U. 2012. Process and technological aspects of municipal solid waste gasification: A review. Waste Management, 32: 625-639.

Barisano, D.; G. Canneto; F. Nanna; E. Alvino; G. Pinto; A. Villone; M. Carnevale; V. Valerio; A. Battafarano and G. Braccio. 2016. Steam/oxygen biomass gasification at pilot scale in an internally circulating bubbling fluidized bed reactor. Fuel Processing Technology, 141: 74-81. 
Cheng, Y.; Z. Thowa and C. Wang. 2016. Biomass gasification with $\mathrm{CO}_{2}$ in a fluidized bed. Powder Technology, 296: 87-101.

Coutoa, N.; A. Rouboaa; V. Silvaa; E. Monteiro and K. Bouziane. 2013. Influence of the biomass gasification processes on the final composition of syngas. Energy Procedia, 36: 596-606.

Dounis, A. I.; M. J. Santamouris; C. C. Lefas and A. Argiriou. 1995. Design of a fuzzy set environment comfort system. Energy and Buildings, 22: 81-87.

Elnady, M. A.; H. A. Hassanien; M. A. Salem and H. M. Samir. 2010. Algal abundances and growth performances of Nile Tilapia (Oreochromisniloticus L.) as affected by different fertilizer sources. Journal of American Science, 6(11): 584-593.

FAO. 2013. Food and Agriculture Organization of the United Nations: Statistical yearbook, world food and agriculture, Rome.

Gomez, E.; D. Amutha; C. Rani; D. Cheeseman; M. Deegan; Wisec and A. Boccaccini. 2009. Thermal plasma technology for the treatment of wastes: a critical review. Journal of Hazardous Materials, 161: 614-626.

Gornowicz, E.; L. Lewko and J. Gornowicz. 2007. Effects of air temperature in the final growing period and of bird strain on carcase and meat quality in broiler chickens. Polish journal of food and nutrition sciences, 57: 4(A): 175-179.

Hamel, S.; H. Hasselbach; S. Weil and W. Krumm. 2007. Auto-thermal two-stage gasification of low-density waste-derived fuels. Energy, 32: 95-107.

Hernandez, J. J.; M. Lapuerta and E. Monedero. 2016. Characterization of residual char from biomass gasification: effect of the gasifier operating conditions. Journal of Cleaner Production, 138: 83-93.

Hinton, M. H. 2000. Infections and intoxications associated with animal feed and forage which may present a hazard to human health. Veterinary Journal, 159(2):124-138. 
Johari, A.; H. Hashim; M. Ramli; M. Jusoh and M. Rozainee. 2011. Effects of fluidization number and air factor on the combustion of mixed solid waste in a fluidized bed. Applied Thermal Engineering, 31: 1861-1868.

Kim, Y. D.; C. W. Yang; B. J. Kim; K. S. Kim; J. W. Lee; J. H. Moon; W. Yang; T. U. Yu and U. D. Lee. 2013. Air-blown gasification of woody biomass in a bubbling fluidized bed gasifier. Applied Energy, 112: 414-420.

Knud-Hansen, C. F.; T. R. Batterson and C. D. McNabb. 1993. The role of chicken manure in the production of Nile tilapia (Oreochromisniloticus L.). Aquaculture and Fisheries Management, 24: 483-493.

Lasa, H.; E. Salaices; J. Mazumder and R. Lucky. 2011. Catalytic steam gasification of biomass: catalysts: thermodynamics and kinetics. Chemical Reviews, 111: 5404-5433.

Lemmens, B.; H. Elslander; I. Vanderreydt; K. Peys; L. Diels; M. Osterlinck and M. Joos. 2007. Assessment of plasma gasification of high caloric waste streams. Waste Management, 27: 1562-1569.

Lin, C. K. and Y. Yi. 2003. Minimizing environmental impacts of freshwater aquaculture and reuse of pond effluents and mud. Aquaculture, 226: 57-68.

Mansaray, K. G.; A. E. Ghaly; A. M. Al-Taweel; F. Hamdullahpur and V. I. Ugursal. 1999. Air gasification of rice husk in a dual distributor type fluidized bed gasifier. Biomass and Bioenergy, 17:315-332.

Mastellone, M. L.; D. Santoro; L. Zaccariello and U. Arena. 2010. The effect of oxygen nenriched air on the fluidized bed co-gasification of coal, plastics and wood. $3^{\text {rd }}$ International Symposium on Energy from Biomass and Waste, Venice, Italy, 8-11.

Moustakas, K.; D. Fatta; S. Malamis; K. Haralambous and M. Loizidou. 2005. Demonstration plasma gasification/vitrification system for 
effective hazardous waste treatment. Journal of Hazardous Materials, 123:120-126.

Nam, H.; A. L. Maglinao Jr.; S. C. Capareda and D. A. RodriguezAlejandro. 2016. Enriched-air fluidized bed gasification using bench and pilot scale reactors of dairy manure with sand bedding based on response surface methods. Energy, 95: 187-199.

OGJ. 2016. Oil and Gas Journal: Africa gaining importance in world LPG trade.http://www.ogj.com/articles/print/volume-95/issue-19/inthisissue/general-interest/africa-gaining-importance-in-world-lpgtrade.html, visited on 25/12/2016

Pauls, J. H.; N. Mahinpey and E. Mostafavi. 2016. Simulation of airsteam gasification of woody biomass in a bubbling fluidized bed using Aspen Plus: A comprehensive model including pyrolysis, hydrodynamics and tar production. Biomass and Bioenergy, 95: 157-166.

Taupe, N. C.; D. Lynch; R. Wnetrzak; M. Kwapinska; W. Kwapinski and J. J. Leahy. 2016. Updraft gasification of poultry litter at farm-scale - A case study. Waste Management, 50: 324-333.

Thakkar, M.; J. P. Makwana; P. Mohanty; M. Shah and V. Singh. 2016. In bed catalytic tar reduction in the auto-thermal fluidized bed gasification of rice husk: Extraction of silica, energy and cost analysis. Industrial Crops and Products, 87: 324-332.

UN. 2016. United Nations: Statistics division energy statistics database. https://knoema.com/UNSDESD2016/un-statistics-division-energystatistics-database-2016, visited on 25/12/2016

Xiao, X.; D. D. Le; K. Morishita; S. Zhang; L. Li and T. Takarada. 2010b. Multistage biomass gasification in internally circulating fluidized bed gasifier (ICFG): test operation of animal-wastederived biomass and parametric investigation at low temperature. Fuel Processing Technology, 91: 895-902. 
Xiao, X.; D. D. Le; L. Li; X. Meng; J. Cao; K. Morishita and T. Takarada. 2010a. Catalytic steam gasification of biomass in fluidized bed at low temperature: Conversion from livestock manure compost to hydrogen-rich syngas. Biomass and Bioenergy, 34: 1505-1512.

Xin, H.; I. L. Berry; G. T. Tabler and T. A. Costello. 2001. Heat and moisture production of poultry and their housing systems: broilers. Transactions of the American Society of Agricultural Engineers, ASAE, 44(6): 1851-1857.

Yi, Y. 1998. A bioenergetics growth model for Nile tilapia (Oreochromisniloticus L.) based on limiting nutrients and fish standing crop in fertilized ponds. Aquacultural Engineering, 18: 157-173.

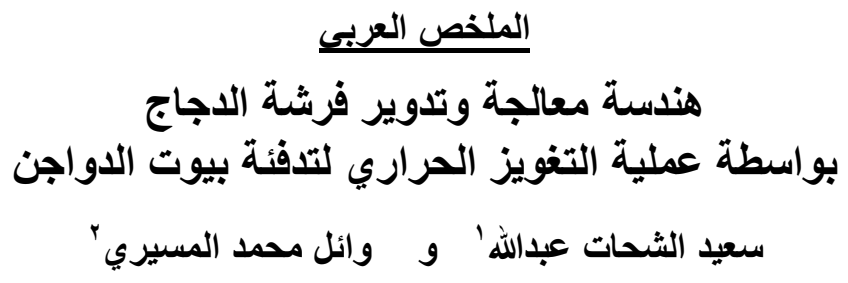

تعتبر صناعة الدواجن من أهم الصناعات الزراعية في مصر، حيث تعمل على سد جزء كبير من الإحتياجات البروتينية إلا أنها تعاني من العديد من المشاكل المرضية المينا المينة في الآونة

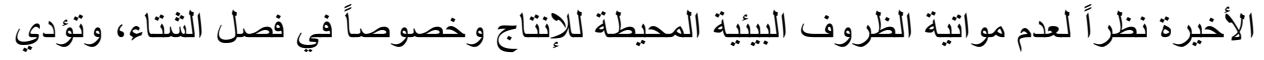

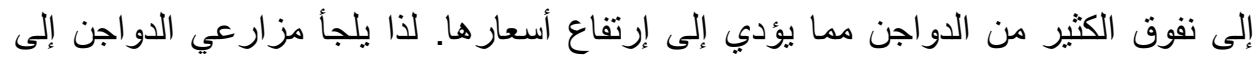

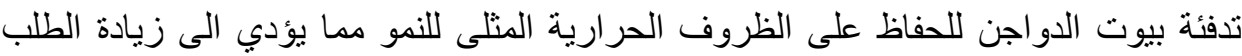

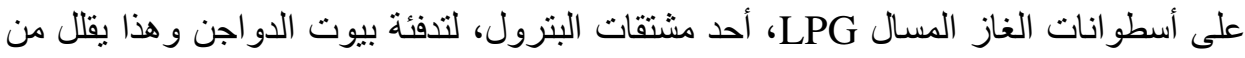

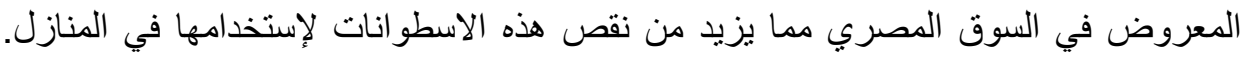

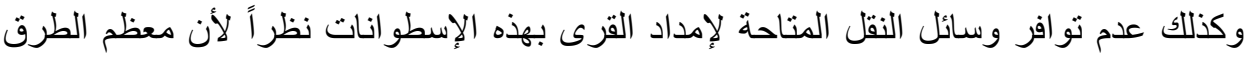

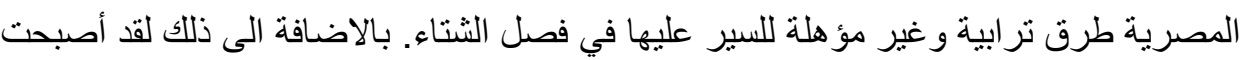

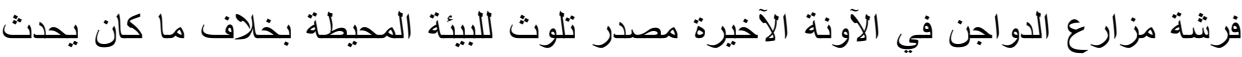

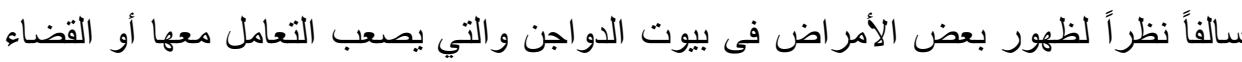

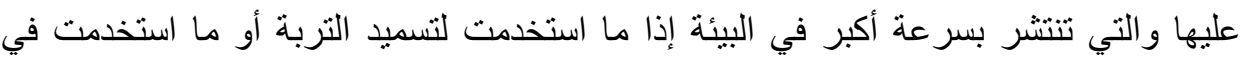

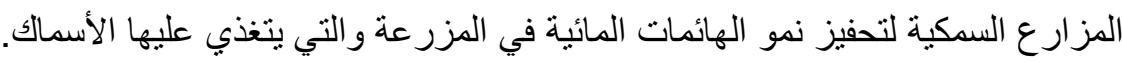

1- أستاذ مساعد ـ قسم الهناسة الزراعية ـ كلية الزراعة ـ جامعة كفرالثيخ ـ كفرالشيخ 1919 هبr ـ مصر

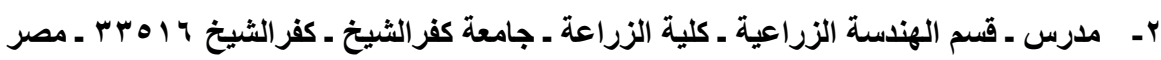


لذا وللأسباب السابقة أصبحت التطبيقات الزر اعية لفرشة بيوت الدو اجن محدودة للحد من تفشي هذه الأمر اض في مناطق زراعية أخري نزيد من حدتها. لذا يهدف هذا البحث إلى إيجاد مصادر طاقة بديلة متاحة فى محيط بيوت الدواجن ولا تحتاج إلى عمليات نقل وإستغلالها في تدفئة بيوت الدواجن مع الأخذ في الاعتبار العامل البيئي في التخلص بطريقة ملائمة من مخلفات مز ارع الدو اجن. تعتبر فرشة الدجاج واحدة من مخلفات صناعة الدواجن و التي يمكن إستغلالها ككتلة حيوية لإستخراج الطاقة منها. تم تطبيق تقنية التغويز الحراري، في الدراسة الحالية، لتحرير الطاقة الحيوية الموجودة بفرشة الدجاج و إستخدامها في تدفئة بيوت الدواجن. تم إختيار

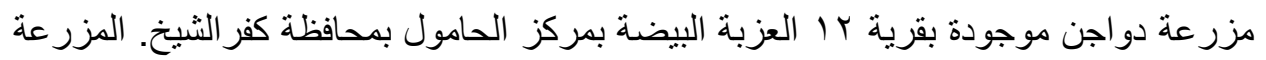

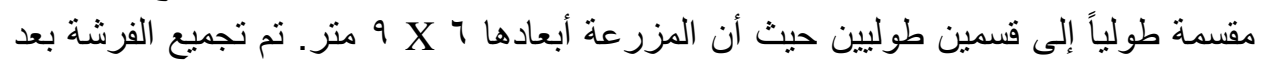

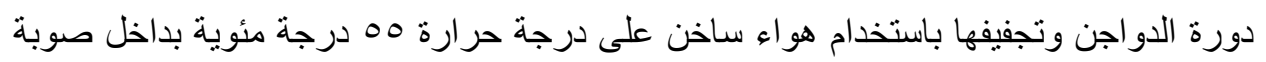

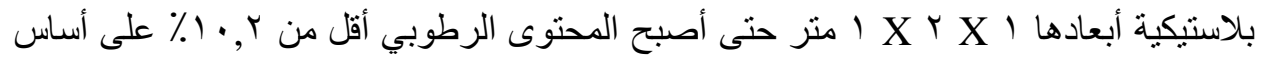

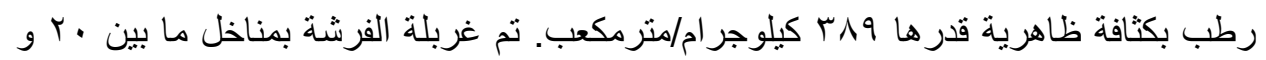

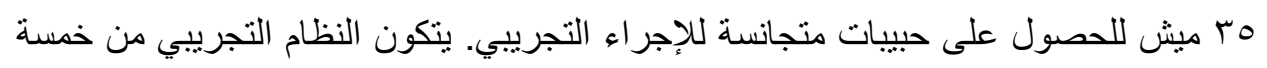

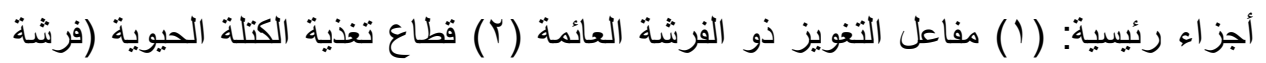

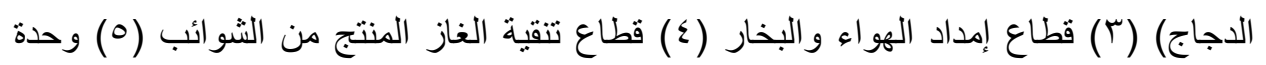
توصيل الطاقة الحرارية إلى بيوت الدواجن. يتكون مخطط النظام الكلي من مبنيين: الأول حجرة المغوز والآخر هو مزرعة الدواجن والتي تتكون من نفقين: نفق الدواجن الأول يتم تدفئته بحرق الغاز الناتج لمعرفة القيمة الحرارية له من خلال التغير في درجة حر ارة الارة النفق الأول، أما

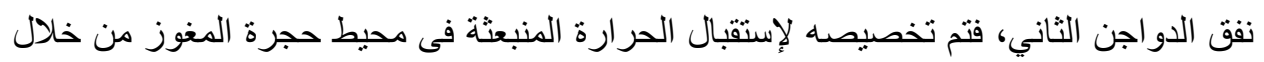
سحب الهواء من هذه الحجرة باستخدام مروحة سحب موجودة في نهاية النفق الثاني.

متغيرات الدراسة لتحديد مدى متغير ات الدر اسة، تم أخذ عينة من فرشة الدجاج لمعرفة كمية الهواء اللازمة لحرق

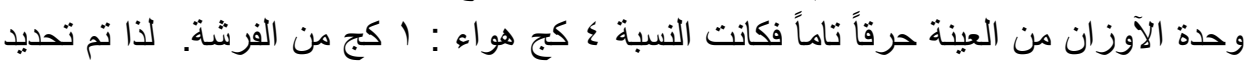

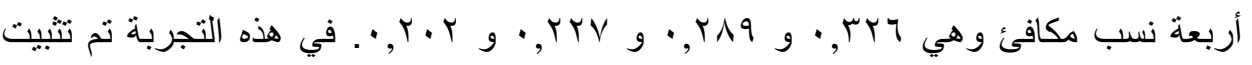
معدل سريان الهو اء (وسيط التغويز) عند 9 •ـ, • كج/ساعة للتحكم في نسب المكافئ من خلال

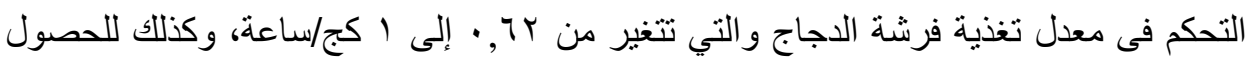

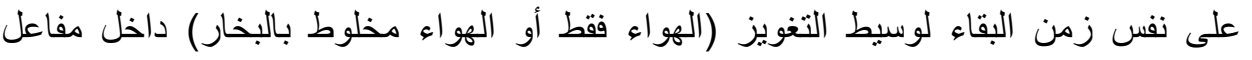
التغويز. تم أخذ ثلاث مستويات من حرارة مفاعل التغويز بعين الإعتبار في هذه الدراسة

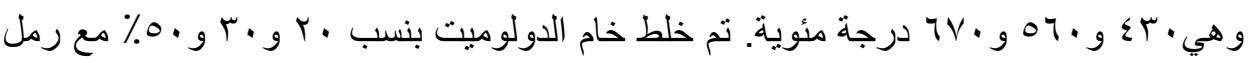

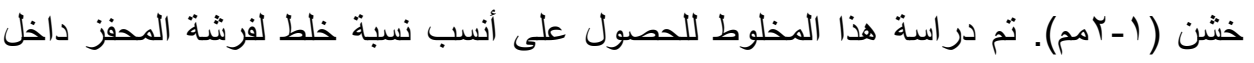
المفاعل. وكذلك تم إختيار وسيطي تغويز وهما الهواء الجوي وهواء مدعم ببخار الماء. تم تحديد معدلات تغذية الفرشة وكذا معدلات سريان الهواء (وسيط التغويز) لمفاعل التغويز بناءاً على مبدأ قانون توازن الطاقة بداخل مزر عة الدو اجن لمعرفة العجز فى مستوى الطاقة، ومن ثم 


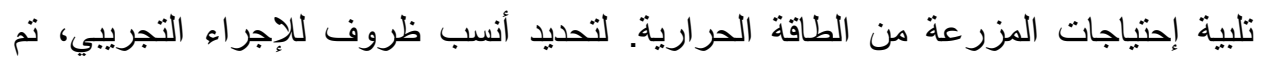

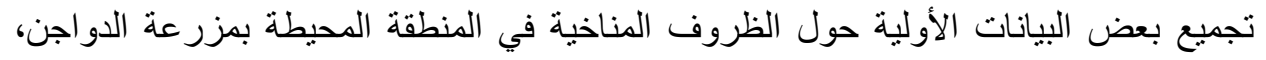

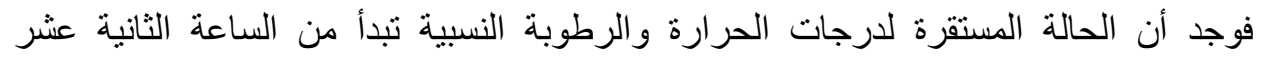

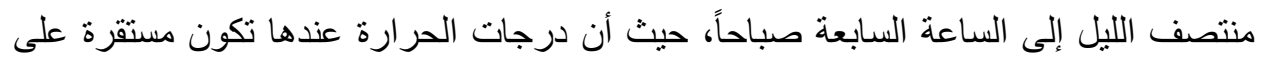

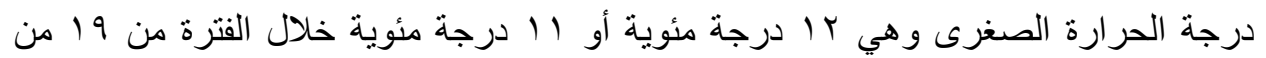

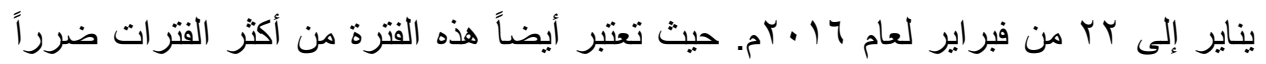

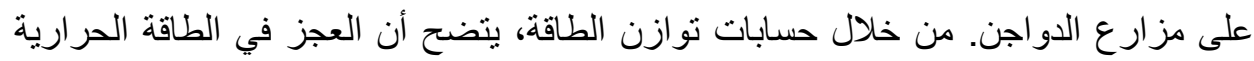

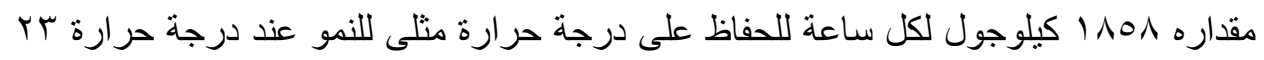

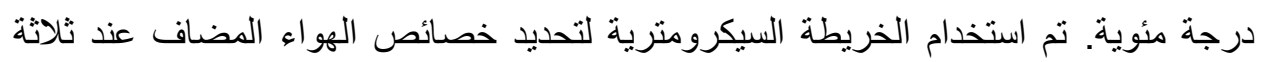

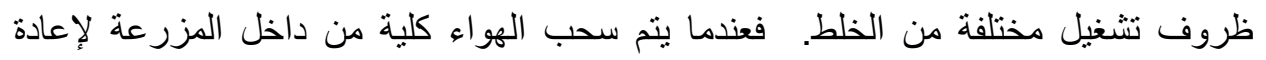

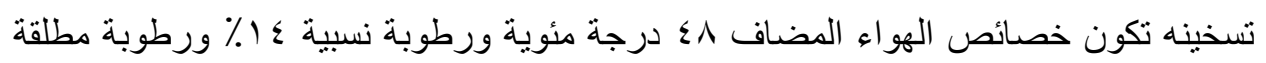

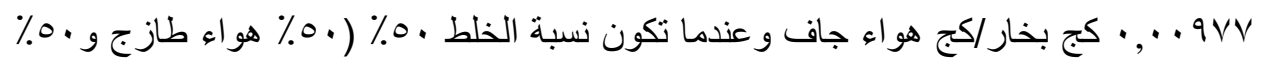

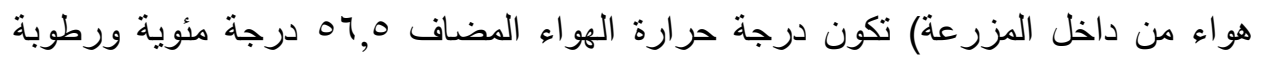

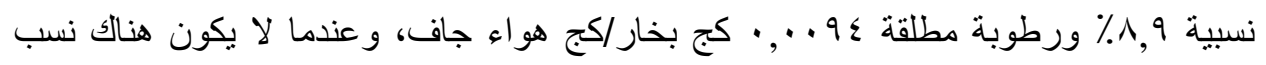

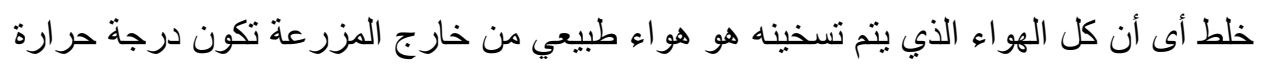

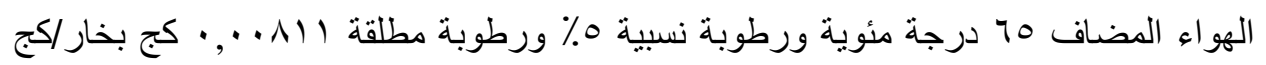

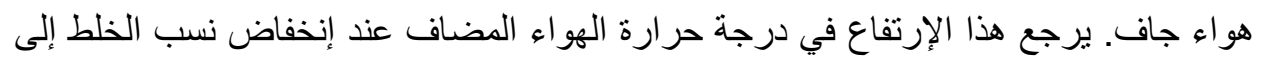

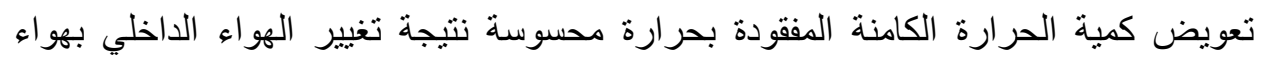

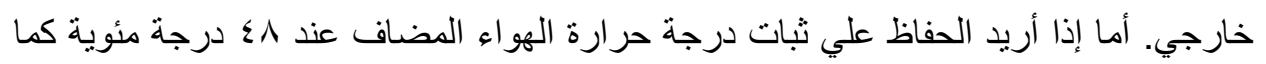

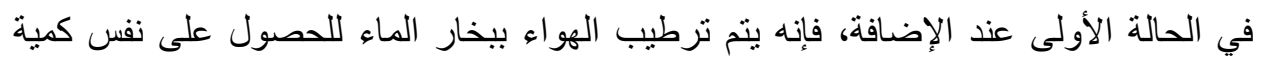

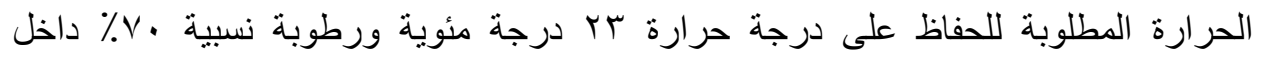

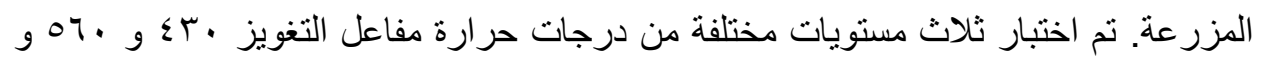

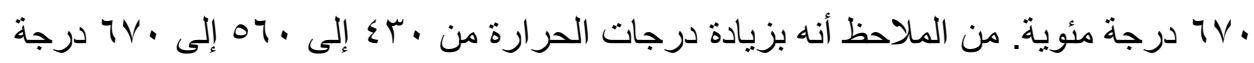

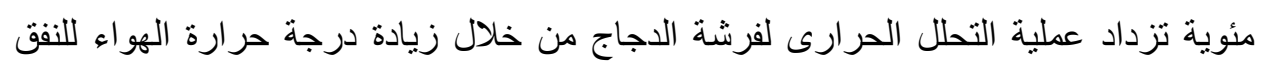

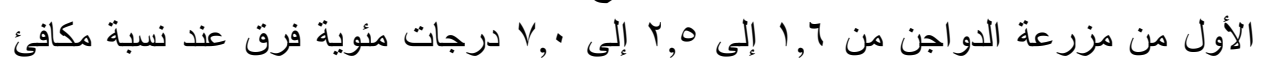

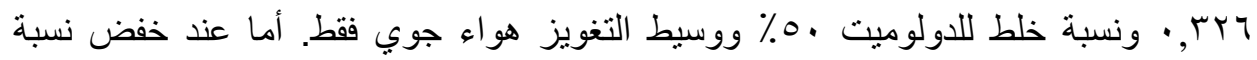

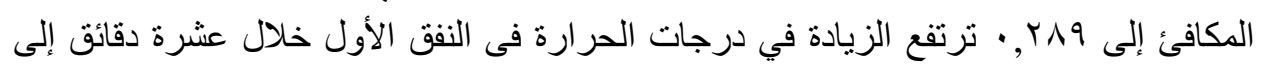

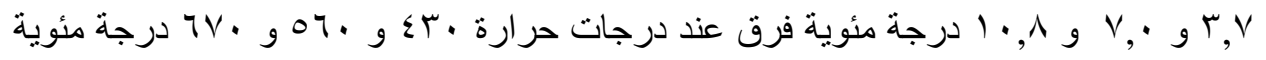

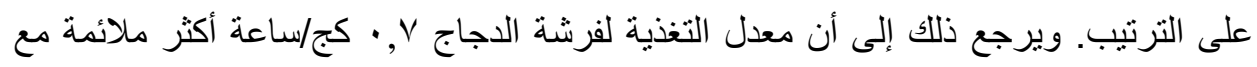

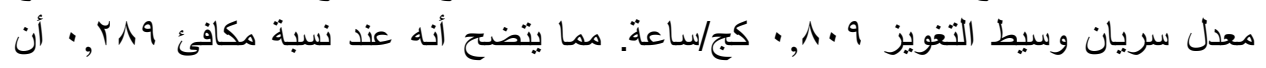

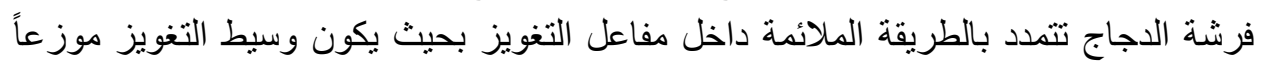

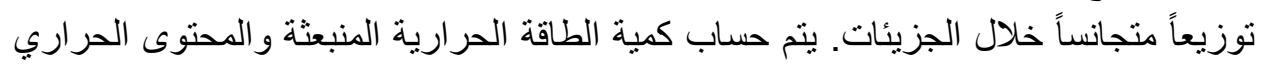

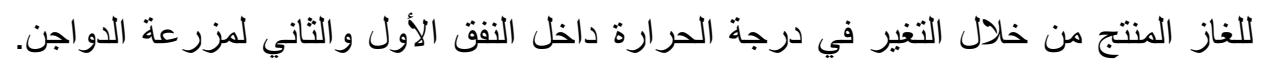


الفرق بين الطاقة المستهلكة لتهيئة مفاعل التغويز والطاقة المتحصل عليها يمثل كمية الطاقة

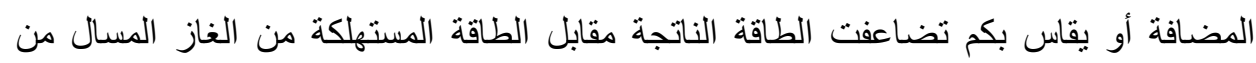

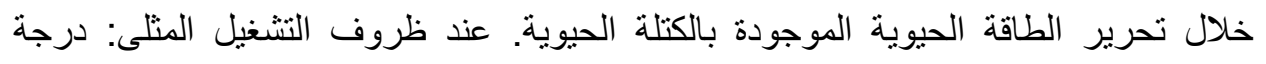

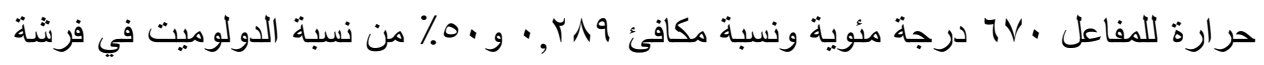

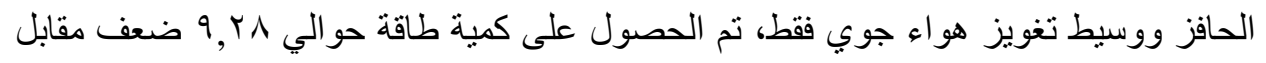

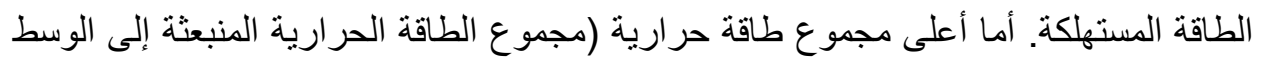

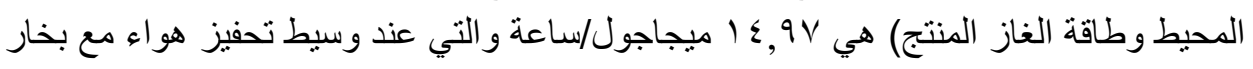

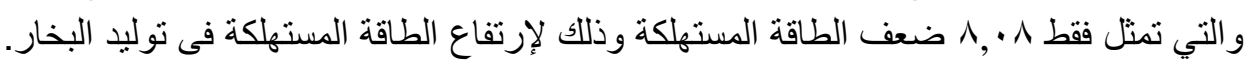

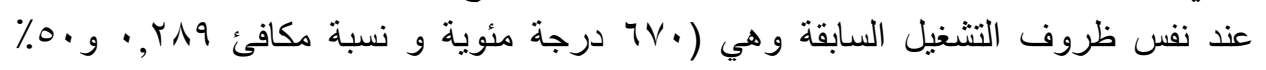

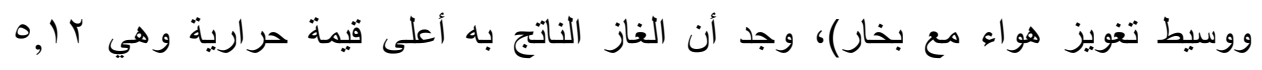

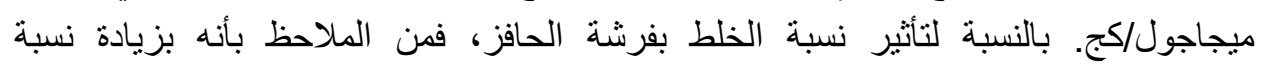

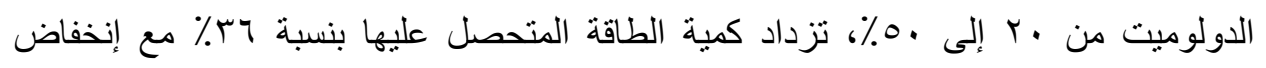
ملحوظ في نسبة القار الناتج مما يزيد من جودة ترداد كبة الغاز المنتج. 